\title{
PISA 2015 Reading Test Item Parameters Across Language Groups: A measurement Invariance Study with Binary Variables*
}

\author{
Pelin BAĞDU SÖYLER * $\quad$ Burak AYDIN ${ }^{* * *} \quad$ Hakan ATILGAN ****
}

\begin{abstract}
Large-scale international assessments, including PISA, might be useful for countries to receive feedback on their education systems. Measurement invariance studies are one of the active research areas for these assessments, especially cross-cultural and linguistic comparability have attracted attention. PISA questions are prepared in the English language, and students from many countries answer the translated form. In this respect, the purpose of our study is to investigate whether there is a measurement invariance problem across native English and non-native English speaker groups in the PISA-2015 reading skills subtest. The study sample included students from Canada, the USA, and the UK as the native speaker group and students from Japan, Thailand, and Turkey as the non-native speaker group. Measurement invariance studies taking into account the binary structure of the data set for these two groups revealed that eight of the twenty-eight items in the PISA-2015 reading skills test had possible limitations in equivalence.
\end{abstract}

Key Words: PISA 2015, measurement invariance (MI), binary variables, reading skills.

\section{INTRODUCTION}

Internationally conducted student assessments play an essential role in the educational policies of countries. One of these assessments is administered by the OECD (Organization for Economic Cooperation and Development) (Milli Eğitim Bakanlı̆̆1-MEB, 2016). The OECD is an institution that plays a vital role in the regulation of the welfare of the world, economic development, and educational policies; it carries out many studies in line with its goals. One of these studies is the International Student Assessment Program (PISA), which is one of the most extensive educational researches in the world implemented internationally. PISA assessments are carried out regularly in fields of mathematics, science, and reading skills. In PISA, the concept of literacy is handled as special equipment used to fulfill a function in life practices. In this extensive study at the international level, equivalence studies are extremely important for ensuring the validity of the measurement instrument. PISA develops different cognitive measurement instruments to measure student performance at all levels in the fields of science and mathematics and contextual measurement instruments (OECD, 2018). One of the main assumptions in this practice, which closely concerns educational policies by comparing student achievements between countries, is that the measured structures are the same for all participants. Construct validity should be ensured by minimizing bias to make valid comparisons between different language groups and countries. Martin, Mullis, Gonzales, Gregory, Garden, O'Connor, Chrostowski and Smith (2000) emphasize the necessity of neutrality while comparing student achievement among countries. Accordingly, construct validity has distinctive importance.

\footnotetext{
*This work is based on the first author's master thesis and preliminary results were presented at AERA 2021 Conference.

**Ministry of Education, İzmir-Türkiye, pelinbagdu@ gmail.com, ORCID ID: 0000-0001-8169-2165

***Assoc. Prof., Ege University, Faculty of Education, İzmir-Türkiye, burak.aydin@ ege.edu.tr, ORCID ID: 0000-0003-44621784

**** Prof., Ege University, Faculty of Education, İzmir- Türkiye, hakan.atilgan@ ege.edu.tr ve 0000-0002-5562-3446, ORCID ID: 0000-0002-5562-3446
}

To cite this article:

Bağdu Söyler, P., Aydın, B., \& Atılgan, H. (2021). PISA 2015 reading test item parameters across language groups: A measurement invariance study with binary variables. Journal of Measurement and Evaluation in Education and Psychology, 12(2), 112-128. doi: 10.21031/epod.800697 
Baykal and Circi (2010) conducted a material revision study to improve the structure validity of PISA 2006 in science testing, and the authors concluded that the different characteristics of the countries should be taken into consideration in stages of item development and translation into different languages by examining the construct validity. Accordingly, it was seen that in international applications such as PISA, the tests are not understood by all participating countries in the same way. Generally, the active role of PISA in national education policies is based on the general assumption that PISA tests are reliable and valid instruments; therefore, this acceptance provides an international comparison of student performances. Researches on this have shown that there are many factors such as translation, item content, curriculum differences, exam motivation or exam anxiety, writing system, and culture. Linguistic diversity affects the comparability of scores and consequently may limit the validity of these studies (Arffman, 2002; Bonnet, 2002; Grisay \& Monseur, 2007; Hambleton, Merenda \& Spielberger, 2005; He \& van de Vijver, 2012; Kreiner \& Christensen, 2014). PISA questions are prepared in English and are used by translating the languages of the countries whose native language is not English. The native language of most of the participating countries is not English, so non-native English-speaking countries use the tests translated into their language. Since PISA significantly affects the educational policies of countries, it is extremely important that the psychometric structure measured between countries and different groups is comparable (Brown, 2006). Scalar equivalence is required to compare the scores obtained from different language versions of the tests in a significant and valid way (Ercikan \& Lyons-Thomas, 2013). In order to compare individuals from different cultures and languages in different subject areas, especially in a direct language-dependent area such as reading skills, it is a critical issue to have no equivalence problems in the structures measured by the tests and to ensure the measurement invariance of the tests.

Arffman (2010) identified six types of problems that limit the equivalence of PISA reading texts. These were language-specific differences in grammar, language-specific differences in writing, languagespecific differences in meaning, differences in culture, translators' choices and strategies, and problems with editing. Accordingly, it is important that the questions are accessible in terms of examining the factors that limit the equivalence of the items and understanding these problems. Based on the analysis of PISA 2006 reading items, Kreiner and Christensen (2014) pointed out that the validity of the measurement model was inadequate due to items with differential item functioning (DIF). As a result, it was not appropriate for countries to compare as such. Some critics have suggested that the PISA reading texts, to some extent, support Western countries, consistent with previous cultural and linguistic concerns. (Grisay et al., 2007; Grisay, Gonzalez \& Monseur, 2009; Oliveri \& von Davier, 2011). Since countries with similar linguistic and cultural histories are likely to hold the equivalence in scores, it is predicted that the MI may be a problem for PISA assessments. (Asil \& Gelbal, 2012; Kankaras \& Moors, 2013).

In the literature, there are many MI studies in PISA student surveys. Asil and Gelbal (2012) investigated MI in terms of culture and linguistics in PISA 2006 student survey. Results revealed that as the cultural and linguistic differences between countries increase, the number of DIF items increases. Segeritz and Pant (2013) studied the Learning Approaches of Students (SAL) scale in the PISA 2003 in Germany sample among ethnic-cultural groups in a country. The findings obtained with the results have shown that the factor structure of the scale Learning Approaches between Germany and two immigrant student groups is comparable.

The equivalence of PISA tests between countries in terms of cultures and language is questionable. The main criticisms point to linguistic and cultural bias, potentially affecting the nature of reading tests. Therefore, the comparisons between countries raise doubts about accuracy. Literacy performance is influenced by a set of characteristics such as the nature of each language, the writing system used to stimulate literacy, the cultural style, teaching and learning approaches, and level of investment in socioeconomic development and education (Asil \& Brown, 2015).

MI of the cognitive data has been tested, and the cultural comparability correlations of the cognitive data have been examined by taking the technical reports as reference. It was concluded that comparing the total scores across different cultures may lead to incorrect results. 
International large-scale applications such as PISA, TIMMS, and PIRLS aim to measure latent structures among participants and compare between groups. However, when these assessments participating in many countries are taken into consideration, some evidence has been obtained that the method is not practical in such large-scale assessments (Rutkowski \& Stevina 2013; Ogretmen, 2006). Rutkowski and Stevina (2013) conducted a simulation study to investigate the change depending on the sample size and the number of groups of multi-group confirmatory factor analysis (MG-CFA) performance. In order to mimic real data, the data were simulated ordinal categorical and analyzed with a linear model. In the findings obtained, it was concluded that there is an inconsistent relationship between a sequential categorical data set and the linear model, so this method selection is not an excellent theoretical practice. In the findings obtained, it was concluded that there is an inconsistent relationship between an ordinal categorical data set and the linear model, so this method is not the right choice in theory. Readers are referred to Jöreskog, Sörbom, Toit and Toit (2001), Sirganci, Uyumaz and Yandi (2020), Gregoric, (2006), Salzberg et al. (1999), Önen (2009), Wu, Li \& Zumbo (2007), and van de Schoot et al. (2013) for further reading on MG-CFA.Therefore, there is an operational need for the suitability of comparisons across countries. In PISA 2015, a recent approach has been applied for MI testing using item response theory (IRT) item consistency (OECD, 2016). Thus, the question raised about the reproducibility of these findings in the context of more common analysis techniques.

In order to compare individuals from different cultures with international measurement instruments, it is essential to hold the equivalence of their forms in different languages when the measurement instrument is translated into other languages. Therefore, measurement invariance is one of the most needed studies in cross-cultural comparisons of multiple groups. It is one of the preconditions to make correct decisions in terms of language skills of cultures and cross-language equivalence in a study playing a significant role in the educational policies of countries such as PISA. Thus, the construction validity studies are very important for the evidence of the validity of the measurement instrument. There are several studies in the literature regarding the MI of PISA; however, it is remarkable that many of the MI analyses ignore the binary nature of the PISA's data sets. PISA questions consist of multiple-choice and partial answer items. In assessments involving such items, it is crucial to perform the MI studies carefully using an appropriate method for the binary nature of the data set in order to achieve valid results.

\section{Measurement Invariance with Different Variable Types}

MI studies provide evidence of the structural validity of the measuring instrument. The equivalence of the characteristic of a psychological measurement instrument, such as construct validity and reliability, in different groups is defined as the measurement invariance (Herdman,1998). Whether the psychological structure to be measured is comparable between groups in terms of different cultural factors or variables is essential for the validity. MI means that a measurement model has the same structure in multiple groups, and the factor structures and error variances of the items in the scale are equivalent (Bollen, 1989).

Evaluation of MI within common factor linear models is known as factorial invariance. When the linear factorial model is used in data sets involving binary, ordered, and Likert-type variables, the structure of the observed variables are ignored (Elosua, 2011). In order to test the MI, the chi-square difference test is used. However, the models are different for continuous and ordinal categorical datasets, so testing the MI between groups requires testing the parameters for each model (Meredith, 1993). While the related parameters are factor loadings and residual variance in a dataset containing continuous variables, the thresholds are required to compare between groups in an ordinal categorical dataset. Using the maximum likelihood estimation (ML) and continuous linear models to analyze ordered categorical datasets involves some disadvantages and uncertainties about the resource of invariance (Lubke \& Muthén, 2004). French and Finch (2006) concluded that the chi-square difference test in evaluating measurement invariance was inadequate in a data set containing multidimensional binary categorical items. Instead of the linear factor analysis commonly used for continuous variables, the variables in the ordered categorical structure can be modeled with MG-CFA in accordance with the threshold structure (Kim \& Yoon, 2011). Since linear CFA is not a suitable analysis for ordered categorical data, the MI test cannot 
be sufficiently compared with linear CFA (McDonald, 1999; Oishi, 2006; Reise et al., 1993). Meade and Lautenschlager (2004) stated that in some cases, the IRT approach could give different and potentially more useful information for modeling MI.

Without modeling the threshold structure, CFA assumes that the underlying distributions of dichotomous or polytomous variables are normal. Threshold values are mathematically related to item difficulty parameters in IRT (Lord \& Novick, 1968; Takane \& de Leeuw, 1987). Accordingly, ordered categorical CFA with the appropriate analysis method based on IRT to test the MI with ordered categorical variables gives more accurate results than linear CFA without considering the threshold structure (Kim \& Yoon, 2011). It should be noted that, especially in PISA assessments, cognitive tests have a binary categorical structure, and attitude scales include Likert-type variables. In other words, analyzing categorical data using methods developed for continuous variables has serious limitations in general (Raykov, Marcoulides \& Milsap, 2013).

\section{Measurement Invariance with Binary Variables}

It has been demonstrated in recent studies that the methods commonly used in MI studies have limitations. As mentioned previously, the MG-CFA method is frequently used for continuous, and Likert-type scored variables. Raykov, Dimitrov, Li, Marcoulides \& Menold (2018) suggested an alternative method for testing the MI with binary scored items. This method aims to determine cases that do not hold the MI with item factor loadings and threshold values. The recent approach does not require defining a reference variable and allows us to study the MI directly with one or two-parameter IRT modeling (Raykov et al., 2018).

IRT suggests that the performance of a person in a test can be predicted according to the item characteristic curve that shows the relationship between the latent traits or abilities (Hambelton and Swaminathan, 1985). IRT is concerned with the participants` responses to each item rather than the total score received from the test. Two item parameters can be used to define the item characteristic curve, which is the basis of IRT. One of these is item difficulty $(b)$, and the other is item discrimination $(a)$ index. Item difficulty states where the item is functional. For example, while an easy item is more functional for individuals with lower ability, a difficult item is more functional for individuals with higher ability levels. The item discrimination index states how well it characterized individuals who are below the ability level of the item and individuals with an ability level above this point (Baker, 2016).

Assume $y=\left(y_{1}, y_{2}, \ldots y_{k}\right)$ represents the components of a psychological scale. In addition, it is assumed that the component $y$ discharges the conditions of structural invariance in groups with large samples (Millsap, 2011). In this setting, a factor analysis model has been developed in each group in which $a$ parameter with loadings and $b$ parameter with thresholds are related. Hence, the necessary conditions for $y$ component and MI of the $g^{\text {th }}$ group are represented as follows;

$$
\begin{gathered}
\mathrm{y}_{\mathrm{g}}{ }^{*}=\Lambda_{\mathrm{g}} \eta_{\mathrm{g}}+\delta_{\mathrm{g}} \\
\Lambda_{1=} \Lambda_{2=\ldots}=\Lambda_{\mathrm{g}} \\
\tau_{1=} \tau_{2=\ldots=}=\tau_{\mathrm{g}}
\end{gathered}
$$

The pair of Equations 2 and 3 also represents a necessary condition to study a two-parameter IRT model or the DIF, a special case of it (Muthén, Asparouhov \& Morin, 2015). DIF states that the probability of responding to the test item correctly is not an equality case in individuals with the same ability level and from different groups (Adams \& Rowe, 1988). DIF analysis aims to investigate whether test scores are affected by variations from different groups and whether these variations give rise to a bias for any subgroup (Algina \& Crocker, 1986). If the attribute measured by the test is the same in different subgroups, it can be seen that the items are affected by the same variability and that individuals with the same ability level are similar in the measured structure (Algina \& Crocker, 1986). The MI analysis method in the binary scored items used in our study provided to test the MI by determining the items under the two-parameter IRT. 


\section{Purpose of the Study}

The purpose of this study is to examine whether the PISA 2015 reading skills subtest is equivalent in terms of language skills for countries with native English and non-native English speakers.In order for comparisons and assessments to be valid, equivalence across cultures and languages should hold. Scales developed in a particular culture and language reflect characteristics of that culture and language. Translating a measurement instrument does not warrant that these two scales are equivalent (Sireci \& Berberoğlu, 2000). It should be noted that the measurement instrument to be translated or adapted to another language will differ from its original form. These differences should be ensured to be acceptable in terms of psychometric properties (Hambleton \& De Jong, 2003). In such a study that plays an essential role in the educational policies of countries, the intercultural equivalence of the tests in terms of language skills is one of the preconditions for making the right decisions (Arffman, 2010; Baykal \& Circi, 2010; $\mathrm{He}$, Barrera-Pedemonte \& Bucholz, 2018). In this respect, it is very important to investigate construct validity carefully for the proof of the validity of the measuring instrument. Hence in this study, whether the reading skills test of the PISA 2015 assessment has MI problem between the translated language form and the original one has analyzed by statistical analysis methods.

\section{METHOD}

Sample sizes of PISA 2015 participant countries included in our study are 14157 from the UK, 5712 from the USA, 20058 from Canada, 6647 from Japan, 8249 from Thailand, and 5895 from Turkey. In PISA, not all students take the same test, and test forms contain common questions as well as different questions (OECD, 2016). A total of 64171 students from selected countries participated in the study. In PISA 2015, 66 different forms were prepared for countries that received computer-based tests. In our study, data from the $41^{\text {st }}$ form were used given that it was the most frequently used form for Canada, UK, the USA, Japan, Thailand, and Turkey. Reading skills achievement was measured in this form with 28 items. The frequencies of the participants who took the $41^{\text {st }}$ form in the sample by country are reported in Table 1.

Table 1 shows that the country with the highest number of participants is Canada with $34.4 \%$, and the USA has the lowest number of participants with $8.9 \%$. The sample of the study consists of 1524 students taken the $41^{\text {st }}$ form from six countries separated out of the countries participating in PISA 2015. The countries included in the research were selected from the countries participating in the PISA 2015 with a computer-based assessment. Therefore, 28 items with the most responded form number 41 selected among 66 different forms were included in the analysis. This form included open-ended and multiplechoice questions. According to the type of question, the items are coded with 0 refers to false responses, 1 refers to partially correct responses, and 2 refers to correct ones. Since the model did not converge with only two partially scored items, the partially correct scores were treated as correct, and items 5 and 6 are re-coded as 0 for incorrect and 1 for correct responses. In our study, the ratio of the missing value to the total sample size was only 6\%, considered low (Kline, 2016, p.83) and hence ignorable (Akbaş \& Tavşanc1l, 2015; Cheema, 2012; Downey and King, 1998; Rubin, 1976; Enders, 2010), and it was decided to exclude the missing data from the analysis to ease the model convergence.

\section{Data Analysis}

A single factor model was tested using CFA for each group. The item parameters obtained with separate CFA were examined. The full measurement invariance approach allows the item factor loadings and threshold values between the comparative groups to be the same, and the approximately defined measurement invariance approach allows only small differences in the parameters in question between the compared groups (Kim, Cao, Wang, \& Nguyen, 2017). Muthén and Asparouhov (2013) bring in the term of approximate measurement invariance as a stage of measurement invariance, in addition to full invariance and partial invariance, with recent studies (van de Schoot et al., 2013).

Findings obtained in this direction have been reported.

Table 1. Sample Sizes Based On Countries 
Bağdu Söyler, P., Aydın, B., Atılgan, H. / PISA 2015 Reading Test Item Parameters Across Language Groups: A Measurement Invariance Study with Binary Variables

\begin{tabular}{lcc}
\hline COUNTRY & $\mathrm{N}$ & $\%$ \\
\hline Canada & 524 & 34.4 \\
UK & 384 & 25.2 \\
Thailand & 176 & 11.5 \\
Japan & 145 & 9.5 \\
Turkey & 159 & 10.4 \\
USA & 136 & 8.9 \\
\hline Total & 1524 & 100 \\
\hline
\end{tabular}

The countries included in this study are separated into two groups as native English (UK, Canada, USA) and non-native English speakers (Japan, Thailand, and Turkey). MI for binary scored items was tested using the Mplus 8.0 (Muthen \& Muthen, 2019). In this direction, item loadings and threshold parameters were free for each item in MI analysis. The difference in BIC values ( $\triangle \mathrm{BIC}$ ) between the baseline model $\left(\mathrm{M}_{0}\right)$ and the free model in each model were studied. The smaller the BIC value, the better the modeldata fit (Nylund, Asparouhov \& Muthén (2007). The model with $\Delta \mathrm{BIC}>10$ indicates a strong misfit of the model, and such values are considered a threat to MI (Frank J., Fabozzi \& Wiley, 2014).

\section{RESULTS}

In the first step, CFA was completed in accordance with the nature of binary variables for each group, and the model fit was examined. The model data fit findings obtained with CFA are presented in Table 2 .

Table 2. Confirmatory Factor Analysis Results of Reading Skills Test PISA 2015

\begin{tabular}{llllll}
\hline Group (Countries) & $\begin{array}{l}\text { Chi-Square } \\
\text { value }\end{array}$ & $\mathrm{n}$ & RMSEA & CFI & TLI \\
\hline Native English Speakers & $409.58^{*}$ & 1044 & .03 & .96 & .97 \\
Non-Native English Speakers & $243.86^{*}$ & 480 & .03 & .97 & .98 \\
\hline
\end{tabular}
$* p<.05$

When the model fit indices in Table 2 are examined, it is seen that the chi-square value is significant in both groups $(p<.05)$. Based on the RMSEA values, it can be understood that the model fits perfectly in both groups since it is .03 for both groups. Concerning CFI and TLI fit indices, it is seen that the CFI value for the native language group indicates a strong fit with .96 and the TLI value with .97 . The CFI and TLI values for the non-native English also indicate a strong fit with .97 and .98 . CFA results indicated that the one-factor structure of PISA 2015 Reading Skills Test holds for both groups separately. Item factor loadings, threshold values, $a$ and $b$ parameters obtained as a result of the CFA analysis are showed in Table 3. 
Table 3. Item Parameters Regarding CFA Results for the Groups Consisting of PISA 2015 Reading Skills Test Language Variable

\begin{tabular}{|c|c|c|c|c|c|c|c|c|}
\hline \multirow[b]{2}{*}{ Item } & \multicolumn{4}{|c|}{ Native English Speakers } & \multicolumn{4}{|c|}{ Non-Native English Speakers } \\
\hline & $\kappa$ & $\mathrm{t}$ & $\mathrm{a}$ & $\mathrm{b}$ & $\kappa$ & $\mathrm{t}$ & $\mathrm{a}$ & $\mathrm{b}$ \\
\hline 1 & 1.00 & -0.81 & 0.64 & -1.50 & 1.00 & -0.38 & 0.95 & -0.56 \\
\hline 2 & 1.01 & -1.13 & 0.65 & -2.07 & 0.99 & -0.35 & 0.93 & -0.51 \\
\hline 3 & 1.06 & -1.26 & 0.70 & -2.20 & 0.88 & -0.64 & 0.76 & -1.06 \\
\hline 4 & 1.10 & -1.07 & 0.74 & -1.80 & 0.65 & -0.62 & 0.51 & -1.37 \\
\hline 5 & 1.23 & -0.90 & 0.88 & -1.36 & 0.61 & -0.41 & 0.46 & -0.97 \\
\hline 6 & 1.25 & -0.92 & 0.91 & -1.36 & 1.03 & -0.51 & 1.02 & -0.71 \\
\hline 7 & 1.18 & 0.67 & 0.82 & 1.06 & 1.03 & 0.76 & 1.01 & 1.06 \\
\hline 8 & 1.00 & 0.33 & 0.64 & 0.61 & 0.83 & 0.69 & 0.71 & -1.24 \\
\hline 9 & 1.31 & -1.15 & 0.99 & -1.64 & 0.84 & -0.72 & 0.71 & -1.24 \\
\hline 10 & 0.88 & 0.79 & 0.54 & 1.68 & 0.98 & 0.98 & 0.93 & 1.45 \\
\hline 11 & 1.17 & -0.06 & 0.82 & -0.09 & 0.83 & 0.22 & 0.70 & 0.39 \\
\hline 12 & 0.99 & -0.08 & 0.63 & -0.14 & 0.51 & -0.13 & 0.38 & -0.36 \\
\hline 13 & 1.19 & -0.79 & 0.84 & -1.23 & 0.97 & -0.54 & 0.90 & -0.81 \\
\hline 14 & 0.90 & -0.06 & 0.56 & -0.12 & 0.70 & 0.08 & 0.55 & 0.17 \\
\hline 15 & 0.50 & 0.37 & 0.28 & 1.36 & 0.45 & 0.53 & 0.32 & 1.73 \\
\hline 16 & 0.63 & -0.24 & 0.36 & -0.70 & 0.60 & 0.08 & 0.46 & 0.20 \\
\hline 17 & 1.07 & -0.86 & 0.71 & -1.48 & 0.76 & -0.76 & 0.62 & -1.26 \\
\hline 18 & 1.31 & -0.88 & 0.99 & -1.25 & 0.76 & -0.69 & 0.61 & -1.33 \\
\hline 19 & 0.91 & -0.07 & 0.56 & -0.14 & 0.67 & 0.10 & 0.53 & 0.22 \\
\hline 20 & 1.22 & -0.41 & 0.87 & -0.62 & 1.02 & 0.17 & 0.99 & 0.24 \\
\hline 21 & 0.20 & -0.14 & 0.85 & -0.22 & 1.06 & 0.30 & 1.07 & 0.41 \\
\hline 22 & 0.99 & -0.26 & 0.63 & -0.49 & 0.85 & -0.47 & 0.72 & -0.81 \\
\hline 23 & 0.87 & -0.83 & 0.53 & -1.77 & 1.02 & -0.34 & 0.98 & -0.48 \\
\hline 24 & 0.81 & 0.16 & 0.48 & 0.36 & 0.84 & 0.39 & 0.71 & 0.68 \\
\hline 25 & 0.79 & -0.10 & 0.47 & -0.21 & 0.73 & 0.53 & 0.58 & 1.06 \\
\hline 26 & 0.77 & -0.94 & 0.46 & -2.26 & 0.60 & -1.15 & 0.45 & -2.78 \\
\hline 27 & 1.02 & -0.32 & 0.66 & -0.57 & 0.53 & -0.27 & 0.40 & -0.64 \\
\hline 28 & 1.26 & 0.58 & 0.92 & 0.86 & 0.96 & 0.73 & 0.88 & 1.10 \\
\hline
\end{tabular}

Note: $\Lambda=$ item factor loading, t: threshold , $\mathrm{a}=$ item discrimination, $\mathrm{b}=$ item difficulty

The item factor loadings, threshold values, $a$ and $b$ parameters obtained from the CFA to examine whether the item parameters of each group differ or not are given in Table 3. It is observed that the $21^{\text {st }}$ item has the least factor loading in the group with native language English, whereas the group with nonEnglish has the greatest factor loading. Accordingly, while factor loadings are expected to be approximately equal with each other for both groups, this case indicates that the item does not work in the same way for both groups. It is understood that the $9^{\text {th }}$ and $18^{\text {th }}$ items in the group with native 
language is English are the ones with the greatest factor loadings. The $15^{\text {th }}$ item is the item with the least factor load (.45) in the group with non-native English and is close to the factor loading (.50) given by the other group in the $15^{\text {th }}$ item. When the factor loadings and the parameters $a$ of the $12^{\text {th }}$ item are compared, the item factor loading of the group with native English is .99, and the parameter $a$ is .63, whereas the item factor loading of the group with non-native English is .51 and the parameter a is .38. These values are substantially different for the items that are expected to measure the equal characteristic.

When we viewed the item threshold values and $b$ parameters, whereas the threshold value is -1.13 for the threshold of the second item in the group with native English, in the group with non-native English, it is-. 35 , and $b$ parameter is -2.07 in the group with native English; the group with non-native English is -0.51 . These values are different for an item that should measure the same characteristic in both groups. Similarly, when the parameters of item 23 are compared in both groups, it is understood that the group with native English is -1.77 and -0.48 in the other group. The CFA results performed separately for the two groups are visually examined. It is difficult to say that items $2,4,6,8,9,12,15,18,21,22,23,25$, 26,27 , and 28 work similarly in psychometric terms. In order to examine whether the 15 differences determined visually are statistically significant, the variation of item parameters and BIC values in 56 different models were examined for the data set consisting of 28 items. The results of MI analysis in binary scored items for the groups with native and non-native English speakers are presented in Tables 4 and 5 .

BIC values obtained from 56 different models to be free of item factor loading and thresholds for each item, their differences from the $\mathrm{BIC}$ value in the $\mathrm{M}_{0}(\triangle \mathrm{BIC})$ and item factor loadings and thresholds are given in Tables 4 and 5. The BIC values of the $\mathrm{M}_{0}$ and the BIC values of each model were compared separately. The BIC value was found to be 44745.34 in $\mathrm{M}_{0}$. The difference of BIC value in each model with BIC value of $\mathrm{M}_{0}$ was calculated. 
Table 4. Measurement Invariance Analysis of PISA 2015 Reading Skills Test Thresholds

\begin{tabular}{|c|c|c|c|c|c|c|c|}
\hline \multirow[b]{2}{*}{ Model } & \multirow[b]{2}{*}{ Par } & \multirow[b]{2}{*}{ BIC } & \multirow[b]{2}{*}{$\triangle \mathrm{BIC}$} & \multicolumn{2}{|c|}{ Group 1} & \multicolumn{2}{|c|}{ Group 2} \\
\hline & & & & $\kappa$ & $\mathrm{t}$ & $\kappa$ & $\mathrm{t}$ \\
\hline M1 & $\mathrm{t}_{1}$ & 44748.62 & 3.28 & - & -1.69 & - & -1.27 \\
\hline M2 & $\mathrm{t}_{2}$ & 44708.93 & $-36.41 *$ & - & -2.35 & - & -1.25 \\
\hline M3 & $\mathrm{t}_{3}$ & 44737.70 & 7.64 & - & -2.69 & - & -2.02 \\
\hline M4 & $\mathrm{t}_{4}$ & 44748.02 & 2.68 & - & -2.21 & - & -1.87 \\
\hline M5 & $\mathrm{t}_{5}$ & 44746.98 & 1.64 & - & -1.84 & - & -1.48 \\
\hline M6 & $\mathrm{t}_{6}$ & 44752.57 & 7.23 & - & -2.14 & - & -2.19 \\
\hline M7 & $\mathrm{t}_{7}$ & 44739.41 & -5.93 & - & 1.66 & - & 1.00 \\
\hline M8 & $\mathrm{t}_{8}$ & 44751.38 & 6.04 & - & 0.71 & - & 0.87 \\
\hline M9 & t9 & 44752.39 & 7.05 & - & -2.76 & - & -2.66 \\
\hline M10 & $\mathrm{t}_{10}$ & 44752.62 & 7.28 & - & 1.65 & - & 1.61 \\
\hline M11 & $\mathrm{t}_{11}$ & 44751.68 & 6.34 & - & -0.10 & - & -0.24 \\
\hline M12 & $t_{12}$ & 44731.95 & $-13.39 *$ & - & -0.14 & - & -0.72 \\
\hline M13 & $\mathrm{t}_{13}$ & 44749.29 & 3.95 & - & -1.78 & - & -2.10 \\
\hline M14 & $\mathrm{t}_{14}$ & 44748.84 & 3.50 & - & -0.10 & - & -0.34 \\
\hline M15 & $t_{15}$ & 44752.65 & 7.31 & - & 0.64 & - & 0.65 \\
\hline M16 & $t_{16}$ & 44748.44 & 3.10 & - & -0.42 & - & -0.17 \\
\hline M17 & $t_{17}$ & 44749.87 & 4.43 & - & -1.79 & - & -2.05 \\
\hline M18 & $\mathrm{t}_{18}$ & 44745.93 & 0.59 & - & -2.01 & - & -2.44 \\
\hline M19 & $\mathrm{t}_{19}$ & 44751.14 & 5.80 & - & -0.13 & - & -0.29 \\
\hline M20 & $\mathrm{t}_{20}$ & 44742.71 & -2.63 & - & -0.84 & - & -0.37 \\
\hline M21 & $\mathrm{t}_{21}$ & 44751.50 & 6.16 & - & -0.21 & - & -0.71 \\
\hline M22 & $\mathrm{t}_{22}$ & 44691.77 & $-53.57 *$ & - & 1.13 & - & -1.58 \\
\hline M23 & $\mathrm{t}_{23}$ & 44745.36 & 0.02 & - & -1.66 & - & -1.30 \\
\hline M24 & $\mathrm{t}_{24}$ & 44752.56 & 7.22 & - & 0.31 & - & 0.27 \\
\hline M25 & $\mathrm{t}_{25}$ & 44722.68 & $-22.66^{*}$ & - & -1.15 & - & 0.58 \\
\hline M26 & $\mathrm{t}_{26}$ & 44725.27 & $-20.07 *$ & - & -1.75 & - & -2.66 \\
\hline M27 & $\mathrm{t}_{27}$ & 44743.97 & -1.37 & - & -0.59 & - & -0.97 \\
\hline M28 & $\mathrm{t}_{28}$ & 44743.49 & -1.85 & - & 1.32 & - & 0.82 \\
\hline
\end{tabular}

Note: $\Lambda=$ item factor loadings; $\mathrm{t}=$ threshold; Grup 1: Native English Speakers Grup 2: Non-Native English Speakers 
Bağdu Söyler, P., Aydın, B., Atılgan, H. / PISA 2015 Reading Test Item Parameters Across Language Groups: A Measurement Invariance Study with Binary Variables

Table 5. Measurement Invariance Analysis of PISA 2015 Reading Skills Test Item Factor Loadings

\begin{tabular}{|c|c|c|c|c|c|c|c|}
\hline \multirow[b]{2}{*}{ Model } & \multirow[b]{2}{*}{ Par } & \multirow[b]{2}{*}{ BIC } & \multirow[b]{2}{*}{$\Delta \mathrm{BIC}$} & \multicolumn{2}{|c|}{ Group 1} & \multicolumn{2}{|c|}{ Group 2} \\
\hline & & & & $\kappa$ & $\mathrm{t}$ & $\kappa$ & $\mathrm{t}$ \\
\hline M29 & $\kappa_{1}$ & 44747.36 & 2.02 & 1.15 & - & 1.57 & - \\
\hline M30 & $\kappa_{2}$ & 44722.44 & $-22.90 *$ & 1.09 & - & 2.09 & - \\
\hline M31 & $\kappa_{3}$ & 44741.84 & -3.50 & 1.20 & - & 1.73 & - \\
\hline M32 & $\kappa_{4}$ & 44752.67 & 7.43 & 1.19 & - & 1.20 & - \\
\hline M33 & $\kappa_{5}$ & 44751.06 & 5.72 & 1.36 & - & 1.17 & - \\
\hline M34 & $\Lambda_{6}$ & 44752.55 & 7.21 & 1.68 & - & 1.74 & - \\
\hline M35 & $\kappa_{7}$ & 44749.53 & 4.19 & 1.30 & - & 1.74 & - \\
\hline M36 & $\kappa_{8}$ & 44752.60 & 7.26 & 1.09 & - & 1.14 & - \\
\hline M37 & $\kappa_{9}$ & 44752.26 & 6.92 & 1.75 & - & 1.65 & - \\
\hline M38 & $\kappa_{10}$ & 44746.56 & 1.12 & 0.92 & - & 1.49 & - \\
\hline M39 & $\kappa_{11}$ & 44748.68 & 4.34 & 1.40 & - & 1.05 & - \\
\hline M40 & $\kappa_{12}$ & 44731.21 & $-24.13 *$ & 1.06 & - & 0.44 & - \\
\hline M41 & $\kappa_{13}$ & 44751.05 & 5.71 & 1.52 & - & 1.33 & - \\
\hline M42 & $\kappa_{14}$ & 44752.08 & 6.74 & 0.89 & - & 0.78 & - \\
\hline M43 & $\kappa_{15}$ & 44752.64 & 7.30 & 0.50 & - & 0.51 & - \\
\hline M44 & $\kappa_{16}$ & 44750.76 & 5.42 & 0.59 & - & 0.77 & - \\
\hline M45 & $\kappa_{17}$ & 44749.77 & 4.43 & 1.28 & - & 1.05 & - \\
\hline M46 & $\kappa_{18}$ & 44736.14 & $-9.20 *$ & 1.75 & - & 1.15 & - \\
\hline M47 & $\kappa_{19}$ & 44751.27 & 5.93 & 0.94 & - & 0.77 & - \\
\hline M48 & $\kappa_{20}$ & 44749.49 & 4.15 & 1.46 & - & 0.86 & - \\
\hline M49 & $\kappa_{21}$ & 44751.57 & 6.23 & 1.46 & - & 1.69 & - \\
\hline M50 & $\kappa_{22}$ & 44736.79 & $-8.55^{*}$ & 1.18 & - & 0.63 & - \\
\hline M51 & $\kappa_{23}$ & 44734.46 & $-10.88 *$ & 0.97 & - & 1.62 & - \\
\hline M52 & $\kappa_{24}$ & 44748.02 & 2.68 & 0.75 & - & 1.11 & - \\
\hline M53 & $\kappa_{25}$ & 44747.32 & 1.98 & 0.78 & - & 1.17 & - \\
\hline M54 & $\kappa_{26}$ & 44739.60 & -5.71 & 0.95 & - & 0.44 & - \\
\hline M55 & $\kappa_{27}$ & 44736.40 & $-8.64 *$ & 1.12 & - & 0.58 & - \\
\hline M56 & $\kappa_{28}$ & 44752.64 & 7.30 & 1.43 & - & 1.40 & - \\
\hline
\end{tabular}

Note: $\Lambda=$ item factor loadings; t=threshold; Grup 1: Native English Speakers Grup 2: Non-Native English Speakers 
Findings showed that $\triangle \mathrm{BIC}$ value of the second item is $-36.41(\triangle \mathrm{BIC}>10)$ in Model 2 and $\triangle \mathrm{BIC}$ value is $-22.90(\triangle \mathrm{BIC}>10)$ in Model 30 . It is evaluated that the threshold values of the second item are quite different from each other, as -2.35 for the group (Group 1) with native English speakers and -1.25 for the group with non-native English speakers (Group 2). Accordingly, it can be said that the second item does not show the model fit and is not comparable for both groups. It is evaluated that $\triangle \mathrm{BIC}$ value of item 18 in Model 46 is a poor fit with $-9.20(6<\Delta \mathrm{BIC}<10)$. Item thresholds and $a, b$ parameters have different values from each other, as seen in Table 3. Similarly, the $\Delta \mathrm{BIC}$ value of item 22 in Model 22 is $-53.57(\triangle \mathrm{BIC}>10)$, and in Model 50 this value is $-8.55(6<\Delta \mathrm{BIC}<10)$. Table 3 is indicated that the parameters of these items differ from each other on the basis of both groups. Items 12, 23, 25, 26, and 27 also seem to have poor model fit. Therefore, it is evaluated that $\triangle \mathrm{BIC}$ values of 8 in 28 items are not in the range of acceptable model fit, and item parameters differ parallel with these results.

\section{DISCUSSION and CONCLUSION}

In this study, the MI of the PISA 2015 Reading Skills Test in terms of the language variable between the countries with native English speakers and the countries with non-native English speakers was tested with binary scored items. For two groups with native and non-native English speakers, CFA was performed separately, and model fit was examined, and it was concluded that overall factor structures were confirmed for each group. Item parameters were compared in both groups with the findings obtained with CFA. It was understood that the factor loadings and threshold parameters of some of the items assumed to measure the same ability in both groups of the PISA 2015 Reading Skills test differ considerably from each other. Therefore, it was concluded that there could be a limitation for the comparability of the groups.

When the item thresholds and factor loadings of these items were compared, it was observed that there was a substantial difference. It was evaluated that 8 out of 28 items in the $41^{\text {st }}$ form of PISA 2015 Reading Skills possibly limit the scalar equivalence. Such a limitation in at least one item means that the MI cannot be fully supported for the whole test (Raykov et al., 2018). Therefore, in this test, it can be concluded that the MI cannot be fully defensible without identifying sources that limit the comparison between English and non-native English groups. In the literature, there are similar MI findings. For example, Baykal and Circi (2010) studied the 2006 PISA science test. The authors asked teachers to evaluate the positive and negative properties of the items, an item evaluation form was created, and the items were categorized according to their content. Negative categories were determined according to culture-specific factors reflected in language, grammatical difficulties, unknown words, and expressions of sentences. Item revisions are completed based on the negative categories. A revised test was created by selecting 22 items from the Turkish version of the science test. With the revised science test, the original science test versions were administered to each of two equivalent groups consisting of 30 students. It was concluded that the group that took the language-wise revised test performed better in all the items compared to the group that took the original translation. A similar study by Asil and Brown (2015) compared the English version of the test and its versions translated into other languages of the PISA 2009 reading skills test. The authors reported that socio-economic factors significantly affect the MI, and linguistic factors are relatively less effective.

In international assessments such as PISA, the questions prepared in English are translated into another language by the expert translators and then translated back to English to ensure its equivalence with the original version. In order to study these factors carefully, information about the effects of the differences in culture and their reflections in the language should be obtained in measurement instruments (Goldstein, 2017). Items that are specific to a language and contain expressions causing bias should be excluded from the test. PISA 2015 science test items are not publicly available, the items that limited the MI could not be examined, and the differences between the results could not be studied in detail. 


\section{REFERENCES}

Adams, R., \& Rowe , K. (1988). Educational research, methodology, and measurement:An international handbook. Oxford: Pergamon Press.

Akbaş, U. ve Tavşancıl, E. (2015). Farklı örneklem büyüklüklerinde ve kayıp veri örüntülerinde ölçeklerin psikometrik özelliklerinin kayıp veri baş etme teknikleri ile incelenmesi., Journal of Measurement and Evaluation in Education and Psychology, 6(1), 38-57

Algina, J. \& Crocker, L., (1986). Introduction to classical and modern test theory. New York: Holt, Rinehart and Winston.

Arffman, I. (2002). In search of equivalence: Translation problems in international literacy studies. Finland.

Arffman, I. (2010). Equivalence of translations in international reading literacy studies. Scandinavian Journal of Educational Research, 54(1), 37-59.

Asil, M., \& Gelbal, S. (2012). Cross-cultural equivalence of the PISA student questionnaire. Education ve Science, 236-249.

Asil M., \& Brown, G. (2015). Comparing OECD PISA reading in English to other languages: Identifying potential sources of non-invariance. International Journal of Testing, 16(1), 71-93.

Baker, F. B. (2016). The basics of item response theory. Ankara: Pegem Academy.

Baykal, A., \& Circi, R. (2010). Item revision to improve construct validity: A study on released science items in Turkish PISA 2006 . Procedia Social and Behavioral Sciences, 2(2), 1931-1935.

Bollen, K. A. (1989). Structural equations with latent variables. New York: Wiley.

Bonnet, G. (2002). Reflections in a critical eye: on the pitfalls of international assessment. Assessment in Education: Principles, Policy \& Practice, 9(3), 387-399.

Brown, T. A. (2006). Confirmatory factor analysis for applied research. New York: Guilford.

Cheema, J. (2012). Handling missing data in educational research using SPSS. Unpublished doctoral dissertation. George Mason University.

Downey, R., \& King, C. (1998). Missing data in likert ratings: A comparison of replacement methods. The Journal of General Psychology, 175-191.

Elosua, P. (2011). Assessing Measurement Equivalence in Ordered-Categorical Data. Psicológica, 403-421.

Enders, C. K. (2010). Applied missing data analysis. (1. Ed.). New York: The Guilford Publications, Inc

Ercikan, K., \& Lyons-Thomas, J. (2013). Adapting test for use in other languages and cultures. APA Handbook of Testing and Assesment in Psychology (s. 545-569). içinde Washington: American Psychological Association.

Frank J. Fabozzi, S. M., \& Wiley , J. (2014). Model Selection Criterion: AIC and BIC. The Basics of Financial Econometrics: Tools, Concepts, and Asset Management Applications.

French, B. F., \& Finch, W. H. (2006). Confirmatory Factor Analytic Procedures for the Determination of Measurement Invariance. Structural Equation Modeling, 13(3), 378-402.

Goldstein, H. (2017). Measurement and evaluation issues with PISA. Routhledge.

Gregoric, S. (2006). Do self-report instruments allow meaningful comparisons across diverse population groups?: Testing measurement invariance using the confirmatory factor analysis framework. Medical Care, 78-94.

Grisay, A., de Jong, J. H., Gebhardt, E., Berezner, A., \& Halleux-Monseur, B. (2007). Translation equivalence across PISA countries. Journal of Applied Measurement, 8(3), 249-266.

Grisay, A., Gonzalez, E., \& Monseur, C. (2009). Equivalence of item difficulties across national versions of the PIRLS and PISA reading assessments. ERI Monograph Series: Issues and Methodologies In Large-Scale Asssesments, 2, 63-84.

Hambelton, R. K., \& Swaminathan , H. (1985). Item Response Theory. Nijhoff Publishing.

Hambleton, R. K., \& De Jong, J. A. (2003). Advances in translating and adapting educational and psychological tests. Language Testing, 127-134.

Hambleton, R. K., Merenda, P., \& Spielberger, C. (2005). Adapting educational and psychological tests for crosscultural assessment. Hillsdale, NJ: Lawrence S. Erlbaum Publishers

Herdman M., Rushby J. F., \& Badia X. (1998). A Model of Equivalence in The Cultural Adaptation of HRQol Instruments: The Universalist Approach. Ouality Of Life Research, 7(4), 323-335.

He, J., Barrera-Pedemonte, F., \& Bucholz, J. (2018). Cross-cultural comparability of non-cognitive constructs in TIMSS and PISA. Assesment in Education:Principles, Policy \& Practice, 26(4), 369-385.

He, J., \& van de Vijver, F. (2012). Bias and equivalence in cross-cultural research. Online Readings in Psychology and Culture.

Jöreskog, K.G., Sörbom, D., Du Toit, S.H.C., \& Du Toit, M. (2001). LISREL 8: New statistical features (3rd ed.). Lincolnwood, IL: Scientific Software International.

Kankaras, M., \& Moors, G. (2013). Analysis of cross-cultural comparability of PISA 2009 scores. Journal of Cross-Cultural Psychology, 43(3), 381-399. 
Kim, E. S., \& Yoon, M. (2011). Testing Measurement Invariance: A Comparison of Multiple-Group Categorical CFA and IRT. Structural Equation Modeling, 212-228.

Kim, E. S., Cao, C., Wang, Y., \& Nguyen, D. T. (2017). Measurement Invariance Testing with Many Groups:A Comparison of Five Approaches. Structural Equation Modeling: A Multidisciplinary Journal.

Kline, R. B. (2016). Principles and practice of structural equation modeling. Guilford publications.

Kreiner, S., \& Christensen, K. B. (2014). Analyses of model fit and robustness. A new look at the PISA scaling model underlying ranking of countries according to reading literacy. Psychometrika, 210-231.

Lord, F. M., \& Novick, M. E. (1968). Statistical theories of mental test scores . MA: Addison-Wesley.

Lubke, G. H., \& Muthén, B. O. (2004). Applying Multigroup Confirmatory Factor Models for Continuous Outcomes to Likert Scale Data Complicates Meaningful Group Comparisons . Structural Equation Modeling A Multidisciplinary Journal, 11(4), 514-534.

Martin, M., Mullis, I., Gonzalez, E., Gregory, K., Smith, T., Chrostowski, S., O'Connor, K. (2000). TIMSS 2009 International Science Report: Findings from IEA's Repeat of The Third International Mathematics and Science Study at the Eight Grade.

McDonald, R. P. (1999). Test theory: A unified treatment. Mahwah: NJ: Lawrence Erlbaum Associates.

Meade, A. W., \& Lautenschlager, G. J. (2004). A comparison of item response theory and confirmatory factor analytic methodologies for establishing measurement equivalence/invariance. Organizational Research Methods,7(4), 361-388.

Milli Eğitim Bakanlığı (2016). PISA 2015 International report. Ankara. [Online: https://odsgm.meb.gov.tr/www/2015-pisa-ulusalraporu/icerik/204], 2016.

Meredith, W. (1993). Measurement invariance, factor analysis, and factorial invariance. Pyschometrika.

Millsap , R. E. (2011). Statistical approaches to measurement invariance. New York: US: Routledge/Taylor \& Francis Group.

Muthén, B., and Asparouhov, T. (2013). BSEM measurement invariance analysis. Mplus Web Notes: No. 17. Available online at: www.statmodel.com

Muthén, B., Asparouhov, T., \& Morin, A. J. (2015). Bayesian Structural Equation Modeling With Cross-Loadings and Residual Covariances: Comments on Stromeyer et al. Journal Of Management.

Muthén, L. K., \& Muthén, B. O. (2019). Mplus user's guide. Los Angeles, CA: Muthén \& Muthén.

Nylund, K.L., Asparouhov, T., \& Muthén, B. (2007). Deciding on the number of classes in latent class analysis and growth mixture modeling. A Monte Carlo simulation study. Structural Equation Modeling, 14, 535569.

Organisation for Economic Co-operation and Development (2016). Online: http://www.oecd.org/education/ ], 2016

Oishi, S. (2006). The concept of life satisfaction across cultures: An IRT analysis. Journal of Research in Personality, 40(4), 411-423.

Ogretmen, T. (2006). Uluslararası okuma becerilerinde gelişim projesi (PIRLS) 2001 testinin psikometrik özelliklerinin incelenmesi: Türkiye-Amerika Birleşik Devletleri örneği. Ankara.

Oliveri, M. E., \& von Davier, M. (2011). Investigation of model fit and score scale comparability in international assessments. Journal of Psychological Test and AssessmentModeling, 53(3), 315-333.

Onen, E. (2009). Ölçme değişmezliğinin yapısal eşitlik modellemesi teknikleri ile incelenmesi. Ankara: Ankara University, Doctoral Thesis.

Raykov, T., Marcoulides, G. A., \& Millsap, R. E. (2013). Examining factorial invariance: A multiple testing procedure. Educational and Psychological Measurement, 73(4), 713-727.

Raykov, T., Dimitrov, D., Marcoulides, G., Li, T., \& Menold, N. (2018). Examining Measurement Invariance and Differential Item Functioning With Discrete Latent Construct Indicators: A Note on a Multiple Testing Procedure. Educational and Psychological Measurement, 78(2), 343-352.

Reise, S. P., Widaman, K. F., \& Pugh, R. H. (1993). Confirmatory factor analysis and item response theory: Two approaches for exploring measurement invariance. Psychological Bulletin, 114(3), 552-566.

Rubin, D. B., (1976). Inference and missing data. Biometrika, 63, 581-592.

Salzberg, T., Sinkovics, R., \& Schlgelmich, B. (1999). Data equivalence in cross-cultural research: a comparison of classical test theory and latent trait theory based approaches. Australasian Marketing Journal, 23-38.

Sireci, S. G., \& Berberoğlu, G. (2000). Using bilingual respondents to evaluate translated-adapted items. Applied Measurement in Education, 13(3), 229-248.

Sirganci, G., Uyumaz, G., \& Yandi, A. (2020). Measurement invariance testing with alignment method: Many groups comparison. International Journal of Assessment Tools in Education, 657-673.

Takane, Y., \& de Leeuw, J. (1987). On the relationship between item response theory and factor analysis of discretized variables. Psychometrika, 52(3), 393-408.

ISSN: 1309 - 6575 Eğitimde ve Psikolojide Ölçme ve Değerlendirme Dergisi

Journal of Measurement and Evaluation in Education and Psychology 
van de Schoot, R., Kluytmans, A., Tummers, L., Lugtig, P., Hox, J., \& Muthén, B. (2013). Facing off with Scylla and Charybdis: A comparison of scalar, partial, and the novel possibility of approximate measurement invariance. Frontiers in Psychology, 4, 1-15.

Wu, D., Li, Z., \& Zumbo, B. (2007). Decoding the meaning of factorial invariance and updating the practice of multi-group confirmatory factor analysis: A demonstration with TIMSS data. Practical Assesment, Research \& Evaluation, 12(3), 1-26. 


\section{Appendix A. Mplus 8.0 Syntax for CFA}

TITLE: CFA for the first group (native English) DATA: FILE IS ING.dat;

VARIABLE: NAMES ARE u1-u28;

CATEGORICAL ARE u1-u28;

MISSING ARE ALL(999);

MODEL: f1 BY u1-u28;

TITLE: CFA for the second group (non-English)

DATA: FILE IS NONING.dat;

VARIABLE: NAMES ARE u1-u28;

CATEGORICAL ARE u1-u28;

MISSING ARE ALL(999);

MODEL: f1 BY u1-u28; 


\section{Appendix B. Mplus 8.0 Syntax for the MI with Binary Variables}

$\mathrm{M}_{0}$ base model:

TITLE: Raykov (2018) M0

DATA: FILE = multicfaALL1 .dat;

VARIABLE: NAMES = g u1-u28;

CATEGORICAL $=\mathrm{u} 1-\mathrm{u} 28$;

KNOWNCLASS $=\mathrm{C}(\mathrm{g}=1 \mathrm{~g}=2) ; \mathrm{g}=1 \mathrm{ING}, \mathrm{g}=2$ NOing

CLASSES = C $(2)$;

MISSING=ALL(999);

ANALYSIS: ESTIMATOR = ML;

TYPE = MIXTURE;

ALGORITHM = INTEGRATION;

MODEL:

\%OVERALL\%

f1 BY u1* (L1)

u2-u28 (L2-L28);

[u1\$1-u28\$1](T1-T28);

[f1@0];

f1@1;

$\% \mathrm{C} \# 2 \%$

f1 BY u1* (L1)

u2-u28 (L2-L28);

[u1\$1-u28\$1](T1-T28);

[f1*];

f1*;

Example syntax to relase a threshold $\left(\mathrm{M}_{1}-\mathrm{M}_{28}\right)$ :

TITLE: Raykov (2018) M1 (relase first threshold)

!LISTWISE=ON;

DATA: FILE = multicfaALL1.dat;

VARIABLE: NAMES = g u1-u28;

CATEGORICAL $=\mathrm{u} 1-\mathrm{u} 28$;

KNOWNCLASS $=\mathrm{C}(\mathrm{g}=1 \mathrm{~g}=2) ; \mathrm{g}=1 \mathrm{ING}, \mathrm{g}=2$ NOing

CLASSES $=\mathrm{C}(2)$;

MISSING=ALL(999);

ANALYSIS: ESTIMATOR = ML;

TYPE = MIXTURE;

ALGORITHM = INTEGRATION;

MODEL:

\%OVERALL\%

f1 BY u1* (L1)

u2-u28 (L2-L28);

[u1\$1-u28\$1](T1-T28);

[f1@0];

f1@1;

$\% \mathrm{C} \# 2 \%$

f1 BY u1* (L1)

u2-u28 (L2-L28);

[u2\$1-u28\$1](T2-T28);

[u1\$1*];

[f1*];

$\mathrm{f} 1 *$; 
Example syntax to relase a loading $\left(\mathrm{M}_{29}-\mathrm{M}_{56}\right)$ :

TITLE: Raykov (2018) M29 (relase first loading)

!LISTWISE $=\mathrm{ON}$;

DATA: FILE = multicfaALL1.dat;

VARIABLE: NAMES = g u1-u28;

CATEGORICAL $=\mathrm{u} 1-\mathrm{u} 28$;

KNOWNCLASS $=\mathrm{C}(\mathrm{g}=1 \mathrm{~g}=2) ; \mathrm{g}=1 \mathrm{ING}, \mathrm{g}=2$ NOing

CLASSES $=\mathrm{C}(2)$;

MISSING=ALL(999);

ANALYSIS: ESTIMATOR = ML;

TYPE = MIXTURE;

ALGORITHM = INTEGRATION;

MODEL:

\%OVERALL\%

f1 BY u1* (L1)

u2-u28 (L2-L28);

[u1\$1-u28\$1](T1-T28);

[f1@0];

f1@1;

$\% \mathrm{C} \# 2 \%$

f1 BY u1*

u2-u28 (L2-L28);

[u1\$1-u28\$1](T1-T28);

[f1*];

f1*; 


\title{
PISA 2015 Dil Gruplarma Göre Madde Parametreleri: İkili Değişkenlerle Ölçme Değiş̧mezliği Çalışması *
}

\author{
Pelin BAĞDU SÖYLER ${ }^{* *} \quad$ Burak AYDIN ${ }^{* * *} \quad$ Hakan ATILGAN ${ }^{* * * *}$
}

\begin{abstract}
$\ddot{O} z$
PISA gibi uluslararası düzeyde yapılan sınavlarda, ülkelerin eğitim sistemlerinin etkililiği hakkında değerlendirmeler yapılmaktadır. Dolayısıyla bu uygulamalar için hazırlanan ölçme araçlarının geçerliği incelenirken farklı değişkenlere göre eşdeğerliğinin sınanması önemli konulardan biridir. PISA uygulamasının soruları İngilizce dilinde hazırlanmaktadır. Birçok ülkeden katılan öğrenciler, testin orijinal formunu değil çeviri formunu cevaplamaktadırlar. PISA'nın uygulama dilinden farklı bir dil kökeninden katılım sağlayan öğrenciler ile testi orijinal formda alan öğrenciler arasında dil değişkenine göre bir ölçme değişmezliği sorunu olmaması gerekmektedir. Bu bağlamda çalışmanın amacı PISA-2015 okuma becerileri alt testinde ana dili İngilizce olan ülkeler ile ana dili İngilizce olmayan ülkelerarasında çeviriden kaynaklanan bir ölçme değişmezliği sorunu olup olmadığını araştırmaktır. Araştırmanın amacı doğrultusunda ana dili İngilizce olan ülkelerden Kanada, ABD ve İngiltere; ana dili İngilizce olmayan ülkelerden ise Japonya, Tayland ve Türkiye örneklemleri araştırmaya dahil edilmiştir. Bu araştırmada PISA-2015 okuma becerileri testinin ana dili değişkenine göre ölçme değiş̧mezliği veri setinin ikili kategorik yapısına uygun olarak test edilmiştir. Yapılan analizler ile elde edilen bulgular doğrultusunda, PISA-2015 okuma becerileri testindeki 28 maddeden 8'inin ana dili İngilizce olan ve olmayan ülkelere göre eşdeğerliğinde büyük ölçüde sınırlamalar olduğu sonucuna ulaşılmıştır. PISA gibi uluslararası sınavların ülkeler arasında karşılaştırılabilir olması için ölçme değişmezliğini sınırlandıran faktörlerin belirlenerek etkisinin en aza indirilmesi gerektiği önerilmiştir.
\end{abstract}

Anahtar Kelimeler: PISA 2015, ölçme değişmezliği, ikili değişkenlerde çok gruplu ölçme değişmezliği analizi

\section{GíRiș}

Ülkelerin eğitim politikalarında önemli rol oynayan uluslararası sınavlardan biri de OECD (Organization for Economic Cooperation and Development) tarafindan yürütülmektedir (MEB, 2016). OECD dünya halklarının refahının, ekonomik kalkınmalarının ve eğitim politikalarının düzenlenmesinde önemli rol oynayan bir kuruluştur. Amaçları doğrultusunda pek çok çalışmalar yapmaktadır. Bu çalışmalardan biri de ülkemizin de katıldığı uluslararası boyutta uygulanan dünyanın en büyük eğitim araştırmalarından olan Uluslararası Öğrenci Değerlendirme Programıdır (PISAProgramme for International Student Assessment). PISA uygulamalar1; matematik, fen ve okuma becerileri konu alanlarında her üç yılda bir düzenli olarak yapılmaktadır. Bu araştırmalar yapılırken ana kavram "okuryazarlık" üzerinde durulmaktadır. PISA'da okuryazarlık kavramı, yaşam pratikleri içinde bir işlevi yerine getirme amaçlı kullanılan bireysel bir donanım olarak ele alınır. Uluslararası düzeyde ülkelerin eğitim çıktılarını değerlendiren bu geniş çaplı araştırmada, eğitim seviyelerinin karşılaştırılabilmesi için ölçme aracının geçerliğinin sağlanması dolayısıyla eşdeğerlik inceleme çalışmaları son derece önemlidir.

Ülkeler arasında öğrenci başarılarını karşılaştırarak eğitim politikalarını yakından ilgilendiren PISA uygulamasında temel varsayımlardan biri de ölçülen yapıların tüm katılımcılar için aynı olmasıdır. Farklı dil grupları ve ülkeler arasında geçerli karşılaştırmalar yapmak için yanlılığı en aza indirerek yapı

\footnotetext{
* Bu çalışma “PISA 2015 Okuma Becerileri Testinin Ana Dili Değişkenine Göre Ölçme Değişmezliğinin İncelenmesi” isimli yüksek lisans tezinden üretilmiştir. AERA 2021'de sözlü bildiri olarak sunulmuştur.

** Milli Eğitim Bakanlığı, İzmir-Türkiye, pelinbagdu@ @mail.com ve 0000-0001-8169-2165

*** Doç. Dr., Ege Üniversitesi, Eğitim Fakültesi, İzmir-Türkiye, burak.aydin@ege.edu.tr ve 0000-0003-4462-1784

**** Prof. Dr., Ege Üniversitesi, Eğitim Fakültesi, İzmir- Türkiye, hakan.atilgan@ege.edu.tr ve 0000-0002-5562-3446
}

Bu makaleye atıfta bulunmak için:

Bağdu Söyler, P., Aydın, B., \& Atılgan, H. (2021). PISA 2015 reading test item parameters across language groups: A measurement invariance study with binary variables. Journal of Measurement and Evaluation in Education and Psychology, 12(2), 112-128. doi: 10.21031/epod.800697 
geçerliği sağlanmalıdır. Martin, Mullis, Gonzales, Gregory, Garden, O'Connor, Chrostowski ve Smith (2000) ülkeler arasında öğrenci başarısını karşılaştırırken yansızlığın gerekliliğini vurgulamaktadırlar. $\mathrm{Bu}$ doğrultuda yapı geçerliliği ayırt edici bir öneme sahiptir. Baykal ve Circi (2010), PISA 2006 uygulamasının fen testinde yapı geçerliğinin geliştirilmesi için madde düzeltme çalışması yapmışlardır. Yazarlar fen testinin Türkçe versiyonundan 22 madde seçerek maddeleri dil açısından düzeltilmiş ve yaptıkları uygulamada dil düzenlemesi yapılan testte öğrencilerin daha başarılı olduklarını raporlamışlardır. $\mathrm{Bu}$ doğrultuda PISA gibi uluslararası uygulamalarda testlerin kültüre ve dile bağlı etkenlerden bağımsız olarak, katılımcı tüm ülkeler tarafından aynı şekilde anlaşılmasının karşılaştırılabilirlik açısından oldukça önemli bir husus olduğu anlaşılmaktadır.

Genel olarak, PISA'nın ulusal eğitim politikalarında etkin rolü, PISA testlerinin güvenilir ve geçerli araçlar olduğu genel kabulüne dayanmaktadır; dolayısıyla bu kabul öğrenci performanslarının uluslararası düzeyde karşılaştırılmasını sağlar. Bununla ilgili yapılan araştırmalar öğrenci performanslarının uluslararası düzeyde karşılaştıılmasında çeviri, madde içeriği, müfredat farklılıkları, sınav motivasyonu veya sınav kaygısı, yazı sistemi ve kültür gibi ölçme eşdeğerliğini etkileyen birçok faktör olduğunu göstermiştir. Dilsel çeşitlilik puanların karşılaştırılabilirliğini etkiler ve sonuç olarak bu çalışmaların geçerliliğini sınırlayabilir (Arffman, 2002; Bonnet, 2002; Grisay ve Monseur, 2007; Hambleton, Merenda ve Spielberger, 2005; He ve van de Vijver, 2012; Kreiner ve Christensen, 2014). PISA soruları İngilizce olarak hazırlanır. Katılımcı ülkelerin bir çoğunun ana dili İngilizce olmadığından ana dili İngilizce olmayan ülkeler testleri kendi dillerine çevrilmiş şekilde kullanırlar. PISA, ülkelerin eğitim politikalarını önemli ölçüde etkilediğinden, ülkeler ve farklı gruplar arası ölçülen psikometrik yapının karşılaştırılabilir olması son derece önemlidir (Brown, 2006). Testlerin farklı dil versiyonlarından alınan puanları anlamlı ve geçerli bir şekilde karşılaştırmak için ölçek denkliği gerekmektedir (Ercikan ve Lyons-Thomas, 2013). Farklı kültür ve dilden katılım gösteren bireylerin farklı konu alanlarında, özellikle de okuma becerileri gibi direkt dile bağlı bir alanda anlamlı olarak karşılaştırılabilmesi için testlerin ölçtüğü yapılarda eşdeğerlik sorunu olmaması, testlerin ölçme değişmezliğinin sağlanması önemli bir husustur.

Arffman (2010), PISA okuma metinlerinin eş değerliğini sınırlayan altı tip problem tespit etmiştir. Bunlar; dilbilgisindeki dile özgü farklılıklar, yazıdaki dile özgü farklılıklar, anlamdaki dile özgü farklılıklar, kültürdeki farklılıklar, çevirmenlerin stratejileri ve düzenleme ile ilgili sorunlardır. Kreiner ve Christensen (2014), PISA 2006 okuma maddeleri analizlerine dayanarak, değişen madde fonksiyonu (DMF) gösteren maddeler nedeniyle ölçme modelinin geçerliğinin yetersiz olduğuna ve sonuç olarak ülkelerin bu şekilde sıralamasının uygun olmadığına dikkat çekmişlerdir. Bazı eleştirmenler, daha önceki kültür ve dil ile ilgili kaygılarla tutarlı olarak, PISA okuma metinlerinin; bir dereceye kadar batı ülkelerinin başarılarını dil ve kültüre bağlı olarak artırabildiği sonucuna varmışlardır.(Grisay ve diğerleri, 2007, Grisay, Gonzalez ve Monseur, 2009; Oliveri ve von Davier, 2011). Benzer dilsel ve kültürel geçmişe sahip ülkelerin puanlarda eşdeğerlik gösterme olasılıkları yüksek olduğundan PISA değerlendirmeleri için ölçme değişmezliğinin sorun teşkil edebileceği ön görülmektedir (Asil ve Gelbal, 2012; Kankaras ve Moors, 2013).

PISA'nın uluslar, kültürler ve diller arasındaki eşdeğerliği tartışmaya açıktır. Temel eleştiriler, okuduğunu anlama testlerinin yapısının potansiyel olarak altında yatan dilbilimsel ve kültürel yanlılığa işaret ederek, ekonomiler arasındaki karşılaştırmaların doğruluğu hakkında şüphe uyandırmaktadır. Okuryazarlık performansı, her dilin doğası, okuryazarlı̆̆ 1 canlandırmak için kullanılan yazı sistemi, kültürel olarak tanımlanmış stil, öğretme ve öğrenme yaklaşımları ile sosyoekonomik kalkınma ve eğitime yatırım seviyeleri gibi birtakım özelliklerden etkilenir (Asil ve Brown, 2015). Asil ve Brown (2015), PISA 2009 okuma becerileri testinin verileriyle testin İngilizce versiyonu ve diğer dillere çevrilmiş versiyonları arasında bir karşılaştırma yapmışlardır. Elde edilen bulgular sonucunda sosyoekonomik faktörlerin ölçme değişmezliğini önemli derece etkilediği, dilsel faktörlerin ise nispeten daha az etkili olduğu görülmüştür.

Farklı kültürlerdeki bireyleri uluslararası ölçme-değerlendirme araçlarıyla karşılaştırmak için, ölçme aracı başka dillere çevrildiğinde farklı dillerdeki formlarının eş değerliğinin sağlanması önemlidir. Bu nedenle çoklu grupların kültürler arası karşılaştırmalarında ölçme değişmezliği en çok ihtiyaç duyulan çalışmalardandır. PISA gibi ülkelerin eğitim politikalarında büyük rol oynayan bir araştırmada testlerin 
dil becerileri açısından kültürler ve diller arası eş değerliğinin sağlanmış olması, doğru kararlar alınmasının ön koşullarından önemli biridir. Dolayısıyla yapı geçerliği çalışmalarının titizlikle yapılması, ölçme aracının geçerlik kanıtı için son derece önemlidir. Alanyazında PISA uygulamalarının ölçme değişmezliğine ilişkin çeşitli çalışmalar mevcuttur. Yapılan çalışmaların bir çoğunda seçilen ölçme değişmezliği analiz yöntemlerinin veri setine uygunluğunun göz önünde bulundurulmamas1 dikkat çekicidir. Ölçme değişmezliği çalışmalarının güvenilir sonuçlarla yapılabilmesi için seçilen yöntemin veri setinin yapısına uygun olması mutlaka göz önünde bulundurulmalıdır.

Ölçme değişmezliği çalışmaları ölçme aracının yapı geçerliğine dair kanıt elde edilmesini sağlar. Psikolojik bir ölçme aracının yapı geçerliği ve güvenirlik gibi özelliklerinin farklı gruplardaki eşitliği ölçme değişmezliği (eşdeğerliğii) olarak tanımlanır (Herdman, 1998). Ölçülecek olan psikolojik yapının farklı kültürel etmenler veya değişkenler açısından gruplar arasında karşılaştırılabilir olup olmadığı ölçme değişmezliği sorununun temelidir. Ölçme değişmezliği, bir ölçme modelinin çoklu gruplarda aynı yapıda olması demektir (Bollen, 1989).

Ölçme değişmezliğinin ortak faktör doğrusal modelleri çerçevesinde değerlendirilmesi faktöriyel değişmezlik olarak bilinir. Bu metodoloji, bir ölçme modelinin farklı gruplar arasındaki parametrelerin eşdeğerliğini değerlendirmek için kullanılır. Doğrusal faktöriyel model ikili, sıralı ve likert tipi değişkenler içeren veri setlerinde kullanıldığında gözlenen değişkenlerin yapısı gözardı edilmiş olur (Elosua, 2011). Ölçme değişmezliğini test etmek için serbest modellerde ki-kare fark testi yapıldığı gibi çok gruplu faktör analizleri de sıklıkla kullanılmaktadır. Fakat sürekli ve sıralı kategorik veri setleri için modeller farklıdır, bu nedenle gruplar arası ölçme değişmezliğini sınamak, parametrelerin her bir model için test edilmesini gerektirir (Meredith, 1993). Sürekli değişkenler içeren bir veri setinde ilgili parametreler faktör yükleri ve artık varyans iken, sıralı kategorik bir veri setinde gruplar arası karşılaştırma yapabilmek için eşik değer parametresine ihtiyaç vardır. Sıralı kategorik veri setlerini analiz etmek için en büyük olabilirlik kestirimi (ML) ile sürekli doğrusal modellerin kullanılması bazı dezavantajlar ve değişmezliğin kaynağı hakkında belirsizlikler içerir (Lubke ve Muthén, 2004). French ve Finch (2006), araştırmalarında çok boyutlu ikili kategorik maddeler içeren veri setinde ki-kare fark testinin ölçme değişmezliğini değerlendirmedeki gücünün oldukça düşük olduğu sonucuna varmışlardır. Sürekli değişkenler için yaygın olarak işe koşulan doğrusal faktör analizi yerine, sıralı kategorik yapıdaki değişkenler eşik yapısına uygun olarak çoklu grup doğrulayıcı faktör analizi (ÇGDFA) ile modellenebilir (Kim ve Yoon, 2011). Ölçme değişmezliği testi, doğrusal doğrulayıcı faktör analizi (DFA) ile madde tepki kuramına (MTK) dayalı DMF analizi ile yeterince karşılaştırılamaz, çünkü doğrusal DFA sıralı kategorik veriler için uygun bir analiz değildir (McDonald, 1999; Oishi, 2006; Reise ve diğerleri, 1993). Meade ve Lautenschlager (2004), bazı durumlarda MTK yaklaşımının ölçme değişmezliğinin kurulması için farklı ve potansiyel olarak daha yararlı bilgiler sağlayabilir olduğunu belirtmiştir. Eşik yapısını modellemeden yapılan doğrusal DFA, gözlemlenen değişkenlerin sürekli ve normal olarak dağıldığını varsayar. Doğrusal DFA, dikotom veya politom puanları sürekli değişkenler olarak ele alır ve kategorik verilerin ayrık özelliğini göz ardı eder; bu da yanlış sonuçlar verebilir. Eşik yapısı dahil edilerek yapılan kategorik DFA, yapısal eşitlik modelindeki kategorik verileri düzgün bir şekilde analiz eder. Eşik değerler, matematiksel olarak MTK'daki zorluk parametreleri ile ilişkilidir (Lord ve Novick, 1968; Takane ve de Leeuw, 1987). Buna göre, sıralı kategorik değişkenlerle ölçme değişmezliğini test etmek için MTK'daki ilgili analitik teknikle yapılan sıralı kategorik DFA, eşik yapısı dikkate alınmadan yapılan doğrusal DFA'ya göre daha doğru sonuç verir.

Raykov, Marcoulides ve Milsap (2013) ölçme değişmezliği belirleme yaklaşımlarını iki kategoriye ayırmıştır; örtük değişken modelleme (latent variable modelling) ve çoklu test metodu (multiple testing method). Birinci yaklaşım kapsamında ölçme değişmezliğini incelemek için en sık kullanılan yöntemlerden biri ÇGDFA'dır (Jöreskog, Sörbom, Toit ve Toit, 2001; akt. Sirganci, Uyumaz ve Yandi, 2020). ÇGDFA aynı zamanda farklı gruplar arasında ölçme sonuçlarının denk olup olmadığı ile ilgili madde yanlılığıly da ilgilenir (Gregoric, 2006; Önen, 2009; Salzberg ve diğerleri, 1999). ÇGDFA analizleri ve ölçme değişmezliği aşamaları analiz edilirken gruplardan biri referans grup olarak belirlenir ve bu gruptaki veriler her aşamada sabitlenip diğer grup ya da gruplara ne derecede uyum sağladığg 1 incelenir. Normal dağılım varsayımı yapılarak ölçme değişmezliği aşamalı olarak test edilmektedir. Her bir aşama, bir önceki aşamanın ön koşulu olarak kabul edilir (Wu, Li ve Zumbo, 2007). Sürekli olmayan 
değişkenlerin (ör. sıralı kategorik) normal dağılan bir örtük değişkenin yansıması olduğu kabulü ve bu kabule uygun tahminleyicilerle ÇGDFA tamamlanabilir. Fakat Raykov, Marcoulides ve Milsap (2013) örtük değişken modelleme yaklaşımının yanıltıcı sonuçlar verebileceğini ve çoklu test yaklaşımının daha az sayıda sınırlılığı olduğunu belirtmiştir.

\section{Íkili Kategorik Değişkenlerde Ölçme Değişmezliği}

Raykov ve ark. (2018) çoklu test yaklaşımının ikili değişkenlerin yapısına uygun olarak kullanımını, 9 sorudan oluşan bir matematik yetenek testinin 771'i erkek, 744'ü kız olan 1515 kişilik bir örnekleme uygulanmasından elde edilen verilerde uygulayarak açıklamışlardır. Her bir madde için eşik değerler ve faktör yükleri serbest bırakılarak temel modelle $\left(\mathrm{M}_{0}\right)$ yapılan karşılaştımaya göre ölçme değişmezliği incelenmiş̧ir. Bu yaklaşım MTK ile örtüşmektedir. MTK, bireyin bir testte gösterdiği performansın örtük özellikler veya yetenekleri ve bir maddedeki performansıyla bu özelliklerin arasındaki ilişkiyi tanımlayan madde karakteristik eğrisine göre kestirilebileceğini öne sürer (Hambelton ve Swaminathan, 1985). MTK her bir maddeye verilen cevabın doğru ya da yanlışlığ ile ilgilenir. Bireyin her bir maddeye vermiş olduğu doğru cevaplar 1, yanlış cevaplar 0 olacak şekilde ikili madde (binary item) formunda puanlanır (Baker, 2016). MTK'nın temeli olan madde karakteristik eğrisini tanımlamak için iki madde parametresi kullanılır. Bunlardan biri madde güçlüğü (b) diğeri ise madde ayırt edicilik (a) indeksleridir. Madde güçlüğü, maddenin hangi noktada işlevsel olduğunu ifade eder. Örnek olarak; kolay bir madde daha düşük yetenek düzeyindeki bireyler için daha işlevsel iken, zor bir madde yüksek yetenek düzeyinde bulunan bireyler için daha işlevseldir. Madde ayırt edicilik indeksi ise, maddenin bulunduğu noktanın altında kalan bireyler ile bu noktanın üzerinde yetenek düzeyine sahip bireyleri ne kadar iyi ayırt edebildiğini gösterir (Baker, 2016).

Bir psikometrik ölçeğin bileşenlerini $\mathrm{y}=\left(\mathrm{y}_{1}, \mathrm{y}_{2}, \ldots, \mathrm{y}_{\mathrm{k}}\right)$ temsil etmektedir. Ayrıca $y$ bileşeninin her biri büyük örneklemlere sahip gruplarda yapısal değişmezliğin koşullarını yerine getirdiği varsayılmaktadır (Millsap, 2011). Bu doğrultuda her bir grupta $a$ parametresi ile faktör yükleri ve $b$ parametresi ile eşik değerlerinin ilişkili olduğu bir faktör analizi modeli geliştirilmiştir. Bu modele göre $g$. grubun $y$ bileşeni ve ölçme değişmezliği için gerekli şartlar aşağıda verilmiştir.

$$
\begin{aligned}
& \mathrm{yg}_{\mathrm{g}}{ }^{*}=\Lambda_{\mathrm{g}} \eta_{\mathrm{g}}+\delta_{\mathrm{g}} \\
& \Lambda_{1=} \Lambda_{2=\ldots}=\Lambda_{\mathrm{g}} \\
& \tau_{1=} \tau_{2=\ldots}=\tau_{\mathrm{g}}
\end{aligned}
$$

Eşitlik 2 ve 3 ayrıca iki parametreli MTK modeli ya da MTK'nın bir özel durumu olan DMF incelemek için yeterli bir şartı temsil etmektedir (Muthén, Asparouhov ve Morin, 2015). Bu yöntemde ilk aşama g-grubu modelinin $k$ ikili maddeleriyle uyum göstermesidir. Burada $k$ ikili puanlanmış maddelerinin kategorik yapısını dikkate alınarak ve kategorik veri setlerinde en büyük olabilirlik kestirimini kullanılmaktadır (Muthen \& Muthen, 2016). Çok gruplu bu modelde; (i) grup özdeşimi için tüm faktör yükleri ve eşik değerler sabit tutulmuştur, (ii) örtük değişkenlerin ortalamaları ve varyansları yalnızca birinci grupta serbest kalmak üzere, sırasıyla 0 ve 1 olarak belirlenmiştir, (iii) $q>1$ ise örtük kovaryans matrisinin köşegen olmayan ögeleri tüm gruplarda serbest bırakılır. Dolayısıyla birinci aşamada uygulanan 2 ve 3 numaralı denklem çifti, yalnızca birinci grupta tüm faktörlerinin ortalama ve varyanslarını sırasıyla 1 ve 0 'a sabitlenip, kalanlarının tüm gruplarda serbest bırakılmasını gerektirir ve $\mathrm{q}>1$ olması durumunda örtük kovaryans matrisi yalnızca birinci (referans) grupta 1'e sabitlenmiş ana köşegen elemanları dışında tüm gruplarda serbest bırakılır. Bu sınırlandırılmış g-grup modeli sürümünü $\mathrm{M}_{0}$ olarak gösterilmiştir. İkinci aşamada,her bir maddenin eşik değerleri yanı sıra faktör yükleri de , $\mathrm{M}_{0}$ 'da tekli parametreler olarak art arda serbest birak1lır ve bu da $2 k$ ilgili model $\mathrm{M}(1), \ldots \mathrm{M}(2 \mathrm{k})$ modelini oluşturur (Raykov, Marcoulides ve Millsap, 2013). Bu $2 k$ modellerin her birinde $\mathrm{M}_{0}$ yuvalanmış (nested) özelliği bulunmaktadır, yani $\mathrm{M}_{0}, \mathrm{M}(1)$ 'den $\mathrm{M}(2 \mathrm{k})$ 'ya kadar tüm modellerde gruplararası eşdeğerlik sınırlılığından bağımsız olan herhangi bir parametreye göre grubun özelliğini belirlemesi için oluşturulmuştur (Raykov, Dimitrov, Li, Marcoulides ve Menold 2018).

DMF ile ilgili tartışmaların bir sonucu olarak, yukarıda verilen Eşitlik 2 ve 3, iki parametreli MTK modelinin tahminlenemeyen ikili maddeler grubu için doğru olması durumunda DMF için yeterli şartı 
sağlamadığını gösterdiği anlaşılmıştır (Lord, 1980). DMF, bir test maddesine aynı yetenek düzeyinde olup farklı gruplardan gelen bireylerin maddeye doğru cevap verme olasılı̆̆ının aynı olmaması durumunu ifade eder (Adams ve Rowe, 1988). DMF analizleri temelde, test puanlarının farklı gruplardan gelen değişkenliklerden etkilenip etkilenmediğini ve bu değişkenliklerin herhangi bir alt grup için bir fayda sağlayıp sağlamadığını araştırmayı amaçlar (Algina ve Crocker, 1986). Test ile ölçülen özellik farklı alt gruplarda aynı ise, maddelerin aynı değişkenlik durumundan etkilendiği ve aynı yetenek düzeyindeki bireylerin ölçülen yapıda da benzer yetenek düzeyinde olduğu söylenebilir (Algina ve Crocker, 1986). Bu çalışmada kullanılan ikili maddelerde ölçme değişmezliği analizi yöntemi, iki parametreli MTK altında DMF gösteren maddeleri belirleme yolu ile ölçme değişmezliğini test etme imkânı sunmuş̧tur.

\section{Araştırmanın Amacı}

Bu çalışmanın genel amacı, PISA 2015 okuma becerileri alt testinin ana dili İngilizce olan ülkeler ile ana dili İngilizce olmayan ülkeler için dil becerileri açısından eşdeğerliğinin sağlanıp sağlanmadığının incelenmesidir. Karşılaştırma ve değerlendirmelerin anlamlı olabilmesi için, kültürler ve diller arası ölçme eşdeğerliğin olması, yani ana dili İngilizce olan ülkeler için herhangi bir yanlılık olmaması gerekmektedir. Belli bir kültürde ve dilde geliştirilmiş ölçekler, o kültüre ve dile özgü nitelik ve kavramsallaştırmaları yansıtır. Bir ölçme aracının bir dilden başka bir dile tercüme edilmesi bu iki ölçeğin eşdeğer olduğunun garantisini vermez (Sireci ve Berberoğlu, 2000). Başka bir dile çevirilecek ya da uyarlanacak ölçme araçlarının orijinal formlarından farklı olacakları bilinmelidir. Söz konusu farklılıkların psikometrik, dil ve anlamlılık açılarından kabul edilebilir düzeyde olmaları sağlanmalıdır (Hambleton ve De Jong, 2003). Ülkelerin eğitim politikalarında büyük rol oynayan böyle bir araştırmada testlerin dil becerileri açısından kültürler arası eşdeğerliğinin sağlanmış olması, doğru kararlar alınmasının ön koşullarından biridir (Arffman, 2010; Baykal ve Circi, 2010; He, Barrera-Pedemonte ve Bucholz, 2018). Tüm bu gereklilikler ışığında yapı geçerliği çalışmalarının titizlikle yapılması, ölçme aracının geçerlik kanıtı için son derece önemlidir. Bu nedenlerle bu çalışmada PISA 2015 uygulamasının okuma becerileri testinin çeviri dil ve orijinal dil arasında herhangi bir ölçme değişmezliği sorunu olup olmadığını istatistiksel analiz yöntemleriyle incelenmiştir.

\section{YÖNTEM}

PISA 2015 uygulamasina İngiltere'den 14157, ABD'den 5712, Kanada'dan 20058, Japonya' dan 6647, Tayland'dan 8249 ve Türkiye'den 5895 öğrenci katılmıştır. Ülkelerin seçimi yapılırken ana dilleri ve okuma becerileri testindeki başarı seviyeleri göz önünde bulundurulmuştur. Araştırmaya dahil edilen altı ülkeden üçü testi orijinal formda alan diğer üçü ise ana dili İngilizce olmayıp testi çeviri formda alan ülkeler arasından seçilmiştir. Kanada ve Japonya okuma becerileri testinde başarılı olan ülkeler arasında olduğu için araştırmaya dahil edilmiştir. İngiltere ve ABD okuma becerileri testinde OECD ortalamasına yakın başarı sağlayan ve Tayland ile Türkiye de başarı sıralamasında OECD ortalamasının altında yer alan ülkelerdir.

PISA uygulamalarında tüm öğrencilere aynı test uygulanmamaktadır. Test formları ortak sorular olduğu gibi farklı sorular da içermektedir (OECD, 2016). Bu çalışmada, bilgisayar tabanlı değerlendirmede uygulanan 66 farklı form arasından, araştırmanın örneklemine dahil edilen ülkeler bazında en çok cevaplanan form olduğu için 41 numaralı form seçilmiştir. Dolayısıyla araştırmanın örneklemini PISA 2015 uygulamasında 41 numaralı formu alan öğrenciler oluşturmaktadır. Okuma becerileri başarısı bu formda 28 madde ile ölçülmüştür. Örneklemde 41 numaralı formu alan öğrencilerin ülkeler bazında frekansları Tablo 1'de verilmiştir. 
Tablo 1. Ülkeler Bazında Örneklem Frekansları

\begin{tabular}{lcc}
\hline Ülke & $\mathbf{N}$ & $\mathbf{\%}$ \\
\hline Kanada & 524 & 34,4 \\
İngiltere & 384 & 25,2 \\
Tayland & 176 & 11,5 \\
Japonya & 145 & 9,5 \\
Türkiye & 159 & 10,4 \\
ABD & 136 & 8,9 \\
\hline Toplam & 1524 & 100 \\
\hline
\end{tabular}

Katılım oranlara bakıldı̆̆ında araştırmanın örnekleminde en fazla katılımcıya sahip ülke \%34,4 ile Kanada ve en az katılımcıya sahip ülke ise \%8,9 oranı ile ABD olduğu anlaşılmaktadır. Araştırmanın örneklemini PISA 2015 uygulamasına katılan ülkelerden seçilmiş altı ülkeden 41 numaralı formu alan toplam 1524 öğrenci oluşturmaktadır. PISA 2015 okuma becerileri alt testi verilerine OECD'nin resmi web sayfasından ulaşılmıştır. Araştırma kapsamına alınan ülkeler PISA 2015 uygulamasına bilgisayar tabanlı değerlendirme ile katılan ülkeler arasından seçilmiştir. Araştırmaya dahil edilen 41 numaralı formda açık uçlu ve çoktan seçmeli maddeler bulunmaktadır. Soru çeşidine göre maddeler yanlış yanıtlar 0 , kısmi doğru yanıtlar 1 , doğru yanıtlar ise 2 ile kodlanmıştır. Verilerin analizi aşamasında modelin tahminlenememesinden dolay 5 . ve 6 . maddelerde 2 kodlu cevaplar 1 olacak şekilde düzenlenmiş, veri seti 0-1 ikili kategorik forma dönüştürülmüştür. Kayıp değerler araştırma sonuçlarını farklı şekilde etkilediği için, araştırmacının örneklem büyüklüğü, kayıp değer oranı gibi etmenleri göze alarak bir karar vermesi gerekmektedir (Cheema, 2012). Kayıp veri sorunu ile ilgili çözüm yolları; kayıp veri ile analize devam etme, eksik verileri analiz dışında bırakma, kayıp veri yerine değer atama ve diğer istatistiksel metodlarla eksik verinin tamamlanması gibi uygulamalardır (Downey ve King, 1998). Kayıp verinin ihmal edilebilirliği, kaybın rastgele olarak oluştuğu, bir başka deyişle bir örüntüye sahip olmadığı ve dolayısıyla da veri dağılımında bir sapma ya da farklılık oluşturmayacağ 1 anlamına gelmektedir (Rubin, 1976; Enders, 2010; akt. Akbaş ve Tavşanc1l, 2015). Araştırmamızda kayıp veri sayısının örneklem büyüklüğüne oranı $\% 6$ olarak hesaplanmış olup, eksik veriler analiz dışı bırakılmıştır (Kline, 2016, s.83).

\section{Verilerin Analizi}

Bu çalışmada öncelikle model her bir grup için ayrı ayrı yapılan DFA ile doğrulanmış, yapı geçerliliğine dair kanıt elde edilmiştir. DFA ile elde edilen madde parametreleri arasındaki ilişki incelenmiştir. Araştırmaya dahil edilen ülkeler ana dili İngilizce olanlar (İngiltere, Kanada, ABD) ve ana dili İngilizce olmayanlar (Japonya, Tayland ve Türkiye) olarak iki gruba ayrılmıştır. Her bir grup için ayrı ayrı DFA yapılarak madde faktör yükleri ve madde eşik değerleri hesaplanmıştır. Her bir maddenin iki grupta da hesaplanan madde parametreleri karşılaştırılmıştır. Daha sonra ölçme değişmezliğini test edilmiştir. Muthén ve Asparouhov (2013), son zamanlarda yapılan çalışmalarla tam değişmezlik ve kısmi değişmezliğe ek olarak, yaklaşık ölçme değişmezliği kavramını da ölçme değişmezliğinin bir aşaması olarak eklemiştir (van de Schoot ve diğerleri, 2013). Yaklaşık ölçme değişmezliği, katı ölçme değişmezliği varsayımını yumuşatır. Yaklaşık ölçme değişmezliği, sonraki analizlerin sonuçlarını etkilemediğini varsayarak paratmetrelerdeki küçük farkl1lıklara izin verir (Kim, Cao, Wang ve Nguyen, 2017).

Mplus 8.0 programı ile veri setinin kategorik yapısı dikkate alınarak Raykov ve ark. (2018) tarafından tanımlanan basamaklara uygun olarak ölçme değişmezliği test edilmiş; bu doğrultuda elde edilen bulgular rapor edilmiştir. Yapılan iki değişkenli maddelerde ölçme değişmezliği analizi ile her bir madde için madde faktör yükleri ve eşik parametreleri serbest bırakılarak $\mathbf{M}_{0}$ serbest modeli oluşturulmuştur. Daha sonra elde edilen her modelde değişimi iki grup arasındaki değişimi incelenen parametre serbest, diğerleri sabit tutularak parametrelerin karşılaştırılması yapılmıştır. Model uyumunu incelemek için $\mathrm{M}_{0}$ 
serbest modelinde ve her bir madde bazında ayrı ayrı Bayesian Information Criterion (BIC) değerleri hesaplanmıștır. Parametre sayıları BIC üzerinde, bir diğer uyum indeksi olan Akaike Information Criterion (AIC) değerine göre daha büyük bir etkiye sahiptir (Frank J., Fabozzi ve Wiley, 2014). Nylund, Asparouhov ve Muthén (2007) bulguları doğrultusunda BIC'nin model iyiliği kriteri olarak kullanılmasına karar verilmiştir. Elde edilen her bir modelin BIC değeri ile $\mathrm{M}_{0}$ serbest modelinin BIC değeri arasındaki farklar bulunmuştur. BIC değerleri arasındaki farkın $(\triangle \mathrm{BIC})$ büyüklüğüne göre modelin iyiliği hakkında sonuca varılmıștır. $6<\Delta \mathrm{BIC}<10$ arasındaki değerler modelin iyi olmadığına dair güçlü, $\Delta \mathrm{BIC}>10$ olan değerler ise çok güçlü bir kanıt sunar. BIC değeri ne kadar küçükse model o kadar iyi demektir. $\mathrm{M}_{0}$ serbest modeline göre daha büyük BIC fark1 veren maddelerin modelle uyumu, bu farkın büyüklüğüyle ters orantılı olarak azalmaktadır (Frank J., Fabozzi ve Wiley, 2014). Bu doğrultuda $\Delta \mathrm{BIC}>10$ olan maddeler oldukça kötü bir model uyumu veriyor anlamına gelir, dolayısıyla ölçme değişmezliği sağlanamadığına dair bir kanıt oluşturmaktadır.

\section{BULGULAR}

Araştırmada öncelikle yapı geçerliğine ilişkin bir kanıt elde etmek amacıyla her bir grup için ikili değişkenlerin yapısına uygun olarak DFA tamamlanmış, standardize edilmemiş faktör yükleri belirlenmiş ve model uyumu incelenmiştir. DFA ile elde edilen bulgular Tablo 2'de verilmiştir.

Tablo 2. PISA Okuma Becerileri Testine İlişkin Doğrulayıcı Faktör Analizi Sonuçları

\begin{tabular}{lccccccc}
\hline Grup (Ülkeler) & $\chi^{2}$ & $\mathrm{df}$ & $\mathrm{p}$ & $\mathrm{n}$ & RMSEA & CFI & TLI \\
\hline Anadili İngilizce Olan & 409.58 & 226 & .00 & 1044 & .03 & .96 & .97 \\
Anadili İngilizce Olmayan & 243.86 & 174 & .00 & 480 & .03 & .97 & .98 \\
\hline
\end{tabular}

Tablo 2'deki model uyum indeksleri incelendiğinde anadili İngilizce olan grupta $\chi^{2}$ değerinin (409.58), serbestlik derecesi (226) ile birlikte anlamlı olduğu görülmektedir $(\mathrm{p}<.05)$. Anadili İngilizce olmayan grupta da $\chi^{2}$ değerinin (243.86), serbestlik derecesiyle (174) birlikte her iki grupta anlamlı olduğu tablodan anlaşılmaktadır $(\mathrm{p}<.05)$. RMSEA değerlerine bakıldığında, her iki grup için de .03 değerinde olduğundan modelin her iki grupta da mükemmel uyum gösterdiğini söylenebilir. CFI ve TLI uyum indeksleri incelendiğinde ise, ana dili İngilizce olan grup için CFI değeri .96 ve TLI değeri ise .97 ile kabul edilebilir uyum sağlamaktadır. Ana dili İngilizce olmayan gruptan CFI değerinin .97 ile kabul edilebilir ve TLI değeri .98 ile iyi model uyumu verdiği görülmektedir. DFA sonuçları PISA 2015 okuma becerileri testinden oluşan yapının her iki grup için de ayrı ayrı model uyumu gösterdiğini ortaya koymaktadır. Her bir gruba ait madde faktör yükleri ve $a, b$ parametrelerinin farklılık gösterip göstermediğini incelemek için yapılan DFA analizi sonucunda elde edilen madde faktör yükleri, eşik değerler, $a$ ve $b$ parametreleri Tablo 3 'te verilmiştir. 
Tablo 3. PISA 2015 Okuma Becerileri Testi Dil Değişkenine Göre Oluşturulan Grupların DFA Sonuçlarına İlişkin Madde Parametreleri

\begin{tabular}{|c|c|c|c|c|c|c|c|c|}
\hline \multirow[b]{2}{*}{ Madde } & \multicolumn{4}{|c|}{ Anadili İngilizce Olan Ülkeler } & \multicolumn{4}{|c|}{ Anadili İngilizce Olmayan Ülkeler } \\
\hline & $\kappa$ & $\mathrm{t}$ & a & $\mathrm{b}$ & $\kappa$ & $\mathrm{t}$ & $\mathrm{a}$ & $\mathrm{b}$ \\
\hline 1 & 1.00 & -0.81 & .64 & -1.50 & 1.00 & -0.38 & .95 & -0.56 \\
\hline 2 & 1.01 & -1.13 & .65 & -2.07 & .99 & -0.35 & .93 & -0.51 \\
\hline 3 & 1.06 & -1.26 & .70 & -2.20 & .88 & -0.64 & .76 & -1.06 \\
\hline 4 & 1.10 & -1.07 & .74 & -1.80 & .65 & -0.62 & .51 & -1.37 \\
\hline 5 & 1.23 & -0.90 & .88 & -1.36 & 61 & -0.41 & .46 & -0.97 \\
\hline 6 & 1.25 & -0.92 & .91 & -1.36 & 1.03 & -0.51 & 1.02 & -0.71 \\
\hline 7 & 1.18 & .67 & .82 & 1.06 & 1.03 & .76 & 1.01 & 1.06 \\
\hline 8 & 1.00 & .33 & .64 & .61 & .83 & .69 & .71 & -1.24 \\
\hline 9 & 1.31 & -1.15 & .99 & -1.64 & .84 & -0.72 & .71 & -1.24 \\
\hline 10 & .88 & .79 & .54 & 1.68 & .98 & .98 & .93 & 1.45 \\
\hline 11 & 1.17 & -0.06 & .82 & -0.09 & .83 & .22 & .70 & .39 \\
\hline 12 & .99 & -0.08 & .63 & -0.14 & .51 & -0.13 & .38 & -0.36 \\
\hline 13 & 1.19 & -0.79 & .84 & -1.23 & .97 & -0.54 & .90 & -0.81 \\
\hline 14 & .90 & -0.06 & .56 & -0.12 & .70 & .08 & .55 & .17 \\
\hline 15 & .50 & .37 & .28 & 1.36 & .45 & .53 & .32 & 1.73 \\
\hline 16 & .63 & -0.24 & .36 & -0.70 & .60 & .08 & .46 & .20 \\
\hline 17 & 1.07 & -0.86 & .71 & -1.48 & .76 & -0.76 & .62 & -1.26 \\
\hline 18 & 1.31 & -0.88 & .99 & -1.25 & .76 & -0.69 & .61 & -1.33 \\
\hline 19 & .91 & -0.07 & .56 & -0.14 & .67 & .10 & .53 & .22 \\
\hline 20 & 1.22 & -0.41 & .87 & -0.62 & 1.02 & .17 & .99 & .24 \\
\hline 21 & .20 & -0.14 & .85 & -0.22 & 1.06 & .30 & 1.07 & .41 \\
\hline 22 & .99 & -0.26 & .63 & -0.49 & .85 & -0.47 & .72 & -0.81 \\
\hline 23 & .87 & -0.83 & .53 & -1.77 & 1.02 & -0.34 & .98 & -0.48 \\
\hline 24 & .81 & .16 & .48 & .36 & .84 & .39 & .71 & .68 \\
\hline 25 & .79 & -0.10 & .47 & -0.21 & .73 & .53 & .58 & 1.06 \\
\hline 26 & .77 & -0.94 & .46 & -2.26 & .60 & -1.15 & .45 & -2.78 \\
\hline 27 & 1.02 & -0.32 & .66 & -0.57 & .53 & -0.27 & .40 & -0.64 \\
\hline 28 & 1.26 & .58 & .92 & .86 & .96 & .73 & .88 & 1.10 \\
\hline
\end{tabular}

Not: $\Lambda=$ madde faktör yükü, $\mathrm{t}=$ madde eşik değeri, $\mathrm{a}=$ madde güçlük, $\mathrm{b}=$ =madde zorluk

Tablo 3'te verilen ana dili İngilizce olan ülkelerden oluşan grup bazında faktör yükleri incelendiğinde en düşük faktör yüküne (.20) sahip 21. maddeyken ana dili İngilizce olmayan ülkelerden oluşan grupta ise en fazla faktör yüküne (1.06) sahip olduğu görülmektedir. Bu doğrultuda her iki grup için de faktör yüklerinin birbirine yakın olması beklenirken, bu durum maddenin her iki grup için farklı çalıştı̆̆ını göstermektedir. Ana dili İngilizce olan grupta 9. ve 18. maddelerin en yüksek faktör yüküne (1.31) sahip 
maddeler olduğu anlaşılmaktadır. 15. madde ana dili İngilizce olmayan grupta en düşük faktör yüküne (.45) sahip maddedir ve diğer grubun 15. maddede verdiği faktör yükü (.50) ile oldukça yakın değerdedir. 12. maddenin faktör yükleri ve a parametreleri karşılaştırıldığında ana dili İngilizce olan grubun madde faktör yükü .99 ve a parametresi .63 iken ana dili İngilizce olmayan grupta madde faktör yükü .51 ve $a$ parametresinin .38 olduğu görülmektedir. Bu değerler aynı özelliği ölçmesi gereken maddeler için birbirinden oldukça farklıdır. Her iki grubun faktör yükleri maddeler bazında karşılaștırıldığında 4, 9, 18,21, 27 ve 28. maddelerin faktör yüklerinin ve a parametrelerinin iki grupta birbirinden oldukça farklı değerler aldığ 1 görülmektedir. Buradan bazı maddelerin her iki grup için de aynı şekilde çalışmadığı söylenebilir.

Madde eşik değerleri ve $b$ parametreleri incelendiğinde 2. maddenin ana dili İngilizce olan grupta eşik değerinin -1.13 iken ana dili İngilizce olmayan grupta - .35 olduğu, $b$ parametrelerinin ise ana dili İngilizce olan grupta -2.07 ; ana dili İngilizce olmayan grupta ise -0.51 olduğu görülmektedir. $\mathrm{Bu}$ değerler her iki grupta da aynı özelliği ölçmesi gereken bir madde için birbirinden oldukça farklı değerlerdir. Benzer şekilde 23. maddenin her iki grupta $b$ parametreleri karşılaştırıldığında ana dili İngilizce olan grupta -1.77 , diğer grupta -0.48 değerini aldığ $6,8,22,25$ ve 26 . maddelere ait eşik değerleri ve $b$ parametrelerinde farklılaşmalar olduğu görülmektedir. Toplamda 28 maddeden oluşan veri seti için 56 farklı modelde madde parametreleri ve $\mathrm{BIC}$ değerleri değişimi incelenmiştir.

Ana dili İngilizce olan ve ana dili İngilizce olmayan her iki gruba ait iki değişkenli puanlanan maddelerde ölçme değişmezliği analizi sonuçları Tablo 4' te verilmiştir. Tablo 4 ve Tablo 5 incelendiğinde her bir madde için madde faktör yükleri ve eşik değerlerinin serbest bırakılması ile 56 farklı modelden elde edilen BIC değerleri, bunların $\mathrm{M}_{0}$ serbest modelindeki BIC değerinden farkları $(\triangle \mathrm{BIC})$ ve madde faktör yükleri ile eşik değerleri yer almaktadır. $\mathrm{M}_{0}$ serbest modelinin BIC değerleri ile her bir modelin BIC değerleri ayrı ayrı karşılaştırılmıştır. 
Tablo 4. PISA 2015 Okuma Becerileri Testi Ölçme Değişmezliği Analizi Eşik Değerler

\begin{tabular}{|c|c|c|c|c|c|c|c|}
\hline \multirow[b]{2}{*}{ Model } & \multirow[b]{2}{*}{ Par } & \multirow[b]{2}{*}{ BIC } & \multirow[b]{2}{*}{$\Delta \mathrm{BIC}$} & \multicolumn{2}{|c|}{ Grup 1} & \multicolumn{2}{|c|}{ Grup 2} \\
\hline & & & & $\kappa$ & $\mathrm{t}$ & $\kappa$ & $\mathrm{t}$ \\
\hline $\mathrm{M}_{0}$ & $\mathrm{t}_{0}$ & 44745.34 & - & - & - & - & - \\
\hline M1 & $\mathrm{t}_{1}$ & 44748.62 & 3.28 & - & -1.69 & - & -1.27 \\
\hline M2 & $\mathrm{t}_{2}$ & 44708.93 & $-36.41 *$ & - & -2.35 & - & -1.25 \\
\hline M3 & $t_{3}$ & 44737.70 & 7.64 & - & -2.69 & - & -2.02 \\
\hline M4 & $\mathrm{t}_{4}$ & 44748.02 & 2.68 & - & -2.21 & - & -1.87 \\
\hline M5 & $t_{5}$ & 44746.98 & 1.64 & - & -1.84 & - & -1.48 \\
\hline M6 & $\mathrm{t}_{6}$ & 44752.57 & 7.23 & - & -2.14 & - & -2.19 \\
\hline M7 & $\mathrm{t}_{7}$ & 44739.41 & -5.93 & - & 1.66 & - & 1.00 \\
\hline M8 & $\mathrm{t}_{8}$ & 44751.38 & 6.04 & - & .71 & - & .87 \\
\hline M9 & $\mathrm{t}_{9}$ & 44752.39 & 7.05 & - & -2.76 & - & -2.66 \\
\hline M10 & $\mathrm{t}_{10}$ & 44752.62 & 7.28 & - & 1.65 & - & 1.61 \\
\hline M11 & $\mathrm{t}_{11}$ & 44751.68 & 6.34 & - & -0.10 & - & -0.24 \\
\hline M12 & $\mathrm{t}_{12}$ & 44731.95 & $-13.39 *$ & - & -0.14 & - & -.72 \\
\hline M13 & $\mathrm{t}_{13}$ & 44749.29 & 3.95 & - & -1.78 & - & -2.10 \\
\hline M14 & $\mathrm{t}_{14}$ & 44748.84 & 3.50 & - & -0.10 & - & -0.34 \\
\hline M15 & $\mathrm{t}_{15}$ & 44752.65 & 7.31 & - & .64 & - & .65 \\
\hline M16 & $t_{16}$ & 44748.44 & 3.10 & - & -0.42 & - & -0.17 \\
\hline M17 & $\mathrm{t}_{17}$ & 44749.87 & 4.43 & - & -1.79 & - & -2.05 \\
\hline M18 & $\mathrm{t}_{18}$ & 44745.93 & .59 & - & -2.01 & - & -2.44 \\
\hline M19 & $\mathrm{t}_{19}$ & 44751.14 & 5.80 & - & -0.13 & - & -0.29 \\
\hline M20 & $t_{20}$ & 44742.71 & -2.63 & - & -0.84 & - & -0.37 \\
\hline M21 & $\mathrm{t}_{21}$ & 44751.50 & 6.16 & - & -0.21 & - & -0.71 \\
\hline M22 & $t_{22}$ & 44691.77 & $-53.57 *$ & - & 1.13 & - & -1.58 \\
\hline M23 & $t_{23}$ & 44745.36 & .02 & - & -1.66 & - & -1.30 \\
\hline M24 & $\mathrm{t}_{24}$ & 44752.56 & 7.22 & - & .31 & - & .27 \\
\hline M25 & $\mathrm{t}_{25}$ & 44722.68 & $-22.66^{*}$ & - & -1.15 & - & .58 \\
\hline M26 & $\mathrm{t}_{26}$ & 44725.27 & $-20.07^{*}$ & - & -1.75 & - & -2.66 \\
\hline M27 & $\mathrm{t}_{27}$ & 44743.97 & -1.37 & - & -0.59 & - & -0.97 \\
\hline M28 & $\mathrm{t}_{28}$ & 44743.49 & -1.85 & - & 1.32 & - & .82 \\
\hline
\end{tabular}

Not: $\Lambda=$ madde faktör yükü, $\mathrm{t}=$ madde eşik değeri

Grup 1: Ana dili İngilizce Olan Ülkeler Grup 2: Ana dili İngilizce Olmayan Ülkeler 
Bağdu Söyler, P., Aydın, B., Atılgan, H. / PISA 2015 Dil Gruplarına Göre Madde Parametreleri: İkili Değişkenlerle Ölçme Değişmezliği Çalışması

Tablo 5. PISA 2015 Okuma Becerileri Testi Ölçme Değişmezliği Madde Faktör Yükleri

\begin{tabular}{|c|c|c|c|c|c|c|c|}
\hline \multirow[b]{2}{*}{ Model } & \multirow[b]{2}{*}{ Par } & \multirow[b]{2}{*}{ BIC } & \multirow[b]{2}{*}{$\Delta \mathrm{BIC}$} & \multicolumn{2}{|c|}{ Grup 1} & \multicolumn{2}{|c|}{ Grup 2} \\
\hline & & & & $\kappa$ & $\mathrm{t}$ & $\kappa$ & $\mathrm{t}$ \\
\hline M29 & $\kappa_{1}$ & 44747.36 & 2.02 & 1.15 & - & 1.57 & - \\
\hline M30 & $\kappa_{2}$ & 44722.44 & $-22.90^{*}$ & 1.09 & - & 2.09 & - \\
\hline M31 & $\kappa_{3}$ & 44741.84 & -3.50 & 1.20 & - & 1.73 & - \\
\hline M32 & $\kappa_{4}$ & 44752.67 & 7.43 & 1.19 & - & 1.20 & - \\
\hline M33 & $\kappa_{5}$ & 44751.06 & 5.72 & 1.36 & - & 1.17 & - \\
\hline M34 & $\Lambda_{6}$ & 44752.55 & 7.21 & 1.68 & - & 1.74 & - \\
\hline M35 & $\kappa_{7}$ & 44749.53 & 4.19 & 1.30 & - & 1.74 & - \\
\hline M36 & $\Lambda_{8}$ & 44752.60 & 7.26 & 1.09 & - & 1.14 & - \\
\hline M37 & $\kappa_{9}$ & 44752.26 & 6.92 & 1.75 & - & 1.65 & - \\
\hline M38 & $\kappa_{10}$ & 44746.56 & 1.12 & .92 & - & 1.49 & - \\
\hline M39 & $\kappa_{11}$ & 44748.68 & 4.34 & 1.40 & - & 1.05 & - \\
\hline M40 & $\kappa_{12}$ & 44731.21 & $-24.13^{*}$ & 1.06 & - & .44 & - \\
\hline M41 & $\kappa_{13}$ & 44751.05 & 5.71 & 1.52 & - & 1.33 & - \\
\hline M42 & $\kappa_{14}$ & 44752.08 & 6.74 & .89 & - & .78 & - \\
\hline M43 & $\kappa_{15}$ & 44752.64 & 7.30 & .50 & - & .51 & - \\
\hline M44 & $\kappa_{16}$ & 44750.76 & 5.42 & .59 & - & .77 & - \\
\hline M45 & $\kappa_{17}$ & 44749.77 & 4.43 & 1.28 & - & 1.05 & - \\
\hline M46 & $\kappa_{18}$ & 44736.14 & $-9.20 *$ & 1.75 & - & 1.15 & - \\
\hline M47 & $\kappa_{19}$ & 44751.27 & 5.93 & .94 & - & .77 & - \\
\hline M48 & $\kappa_{20}$ & 44749.49 & 4.15 & 1.46 & - & .86 & - \\
\hline M49 & $\kappa_{21}$ & 44751.57 & 6.23 & 1.46 & - & 1.69 & - \\
\hline M50 & $\kappa_{22}$ & 44736.79 & $-8.55^{*}$ & 1.18 & - & .63 & - \\
\hline M51 & $\kappa_{23}$ & 44734.46 & $-10.88^{*}$ & .97 & - & 1.62 & - \\
\hline M52 & $\kappa_{24}$ & 44748.02 & 2.68 & .75 & - & 1.11 & - \\
\hline M53 & $\kappa_{25}$ & 44747.32 & 1.98 & .78 & - & 1.17 & - \\
\hline M54 & $\kappa_{26}$ & 44739.60 & -5.71 & .95 & - & .44 & - \\
\hline M55 & $\kappa_{27}$ & 44736.40 & $-8.64 *$ & 1.12 & - & .58 & - \\
\hline M56 & $\kappa_{28}$ & 44752.64 & 7.30 & 1.43 & - & 1.40 & - \\
\hline
\end{tabular}

Not: $\Lambda=$ madde faktör yükü, $\mathrm{t}=$ madde eşik değeri, Grup 1: Ana dili İngilizce Olan Ülkeler Grup 2: Ana dili İngilizce Olmayan Ülkeler

$\mathrm{M}_{0}$ serbest modelinde BIC değeri 44745.34 olarak bulunmuştur. Her bir modeldeki BIC değerinin bu değerle farkı hesaplanmıştır. Elde edilen bulgulara göre, 2. maddenin Model 2'de $\Delta \mathrm{BIC}$ değerinin - 
$36.41(\Delta \mathrm{BIC}>10)$ ve Model 30'da $\Delta \mathrm{BIC}$ değerinin -22.90 ( $\triangle \mathrm{BIC}>10)$ olduğu görülmektedir. 2. maddeye ait eşik değerlerinin de ana dili İngilizce olan ülkelerden oluşan grup (Grup 1) için -2.35 ve ana dili İngilizce olmayan ülkelerden oluşan grup için (Grup 2) -1.25 değerleriyle birbirinden oldukça farklı olduğu anlaşılmaktadır. Bu doğrultuda 2. maddenin model uyumu göstermediği ve her iki grup için de karşılaştırılabilir olmadığı söylenebilir. Madde 18'in Model 46'daki $\Delta$ BIC değerinin -9.20 $(6<\Delta \mathrm{BIC}<10)$ ile yine kötü model uyumu veren aralıkta olduğu anlaşılmaktadır. Madde eşik değerleri ve $a, b$ parametrelerinin de birbirinden farklı değerler aldığı Tablo 3 'ten görülmektedir. Benzer şekilde madde 22'nin Model 22'deki $\Delta \mathrm{BIC}$ değerinin $-53.57(\Delta \mathrm{BIC}>10)$ ve Model 50 'de bu değerin -8.55 $(6<\Delta \mathrm{BIC}<10)$ olduğu görülmektedir. Bu maddelere ait parametrelerin de her iki grup bazında birbirinden farklılaştığı yine Tablo 3'ten anlaşılmaktadır. Benzer şekilde 12, 23, 25,26 ve 27. maddelerin de kötü uyum verdiği görülmektedir.

Elde edilen bulgulara göre 28 maddeden oluşan PISA-2015 okuma becerileri testinin 8 maddesinin ölçme değişmezliğini tam olarak sağlamadığı söylenebilir. İkili puanlanmış maddelerde ölçme değişmezliği analizi ile ulaşılan sonuçlarda en az bir maddenin ölçme değişmezliğini tam olarak sağlamaması, testin ölçme değişmezliğini sınırlandırarak testin bütününde bir ölçme değişmezliği sorun olabileceğini ortaya koymaktadır (Raykov ve ark., 2018).

\section{SONUÇLAR ve TARTIŞMA}

Bu araştırmada PISA 2015 okuma becerileri testinin ana dili İngilizce olan ülkeler ile ana dili İngilizce olmayan ülkeler arasında dil değişkeni açısından ölçme değişmezliği ikili puanlanmış maddelerin yapısına uygun olarak test edilmiş̧ir. Veri setinin ikili kategorik yapısına uygun olarak ölçme değişmezliği analizi yapılmıştır. Ana dili İngilizce olan ve ana dili İngilizce olmayan ülkelerden oluşan iki grup için ayrı ayrı DFA yapılarak model uyumu incelenmiş, faktör yapılarının her bir grup için doğrulandığ 1 sonucuna ulaşılmıştır. DFA ile elde edilen bulgularla her bir maddenin ana dili İngilizce olan ve ana dili İngilizce olmayan gruplarda faktör yükleri ve eşik parametreleri karşılaştırılmıştır. PISA 2015 okuma becerileri testinin her iki grupta aynı özelliği ölçtüğü varsayılan maddelerinin bazılarının faktör yükleri ve eşik parametrelerinin birbirinden oldukça farklı olduğu anlaşılmıştır. Dolayısıyla bu durumun, ana dili değişkenine göre oluşturulan grupların birbirileriyle karşılaştırılabilirlikleri için bir sinırlılık olabileceği sonucuna varılmıştır.

Gruplar arasında ölçme değişmezliğini incelemek için ikili puanlanmış maddelerin yapısına uygun analizler yapılmıştır. Elde edilen bulgulara göre DFA sonuçlarına paralel olarak, ölçme değiş̧mezliğini sağlamadığı düşünülen maddelerde serbest modele $\left(\mathrm{M}_{0}\right)$ göre $\mathrm{BIC}$ değerlerinin daha büyük olduğu, bu farkların 6 ile 10 arasında ya da 10'dan büyük olduğu dolayısıyla modele uyumunun azaldığ1 belirlenmiştir. Bu maddelere ilişkin madde eşik değerleri ve faktör yükleri karşılaştırılmıştır. Model uyumu düşük olan maddelerin bir çoğunda madde eşik değerleri ve faktör yüklerinin de birbirinden farklı olduğu görülmüştür. Bu doğrultuda PISA 2015 okuma becerileri testinin 41 numaralı formunda yer alan 28 maddeden 8'inin ana dili değişkenine göre oluşturulan gruplar arasında karşılaştırma yapılmasını ciddi şekilde sınırladığı sonucuna varılmıştır. En az bir maddede böyle bir sınırlılık olması testin bütünü için ölçme değişmezliğinin tam olarak sağlanamadığı anlamına gelmektedir (Raykov ve ark., 2018). Dolayısıyla bu testte ölçme değişmezliğinin, ana dili İngilizce olan ülkeler ile ana dili İngilizce olmayan ülkelerden oluşan gruplar arasında karşılaştırılabilir olmasına kısıtlamalar getiren kaynaklar tanımlanmadan tam olarak yorumlanamayacağı yargısına varılabilir. Alanyazında bu çalışmanın bulgularından ulaşılan sonuçlarla aynı doğrultuda olan ölçme değişmezliği çalışmaları bulunmaktadır, bir diğer ifade ile, çalışma bulguları alanyazınla tutarlıdır. Örneğin, Ercikan ve Koh (2005), 1995 yılında uygulanan TIMSS verilerini kullanarak İngilizce ve Fransızca versiyonlarının ölçme değişmezliğini araştırmışlardır. Araştırmaya Kanada'dan katılan öğrenciler dahil edilmiştir. Madde tepki kuramı ve çok gruplu doğrulayıcı faktör analizi ile karşılaştırmalar yapılmış; matematik ve fen sınavlarının İngilizce ve Fransızca dilindeki verisyonlarında önemli farklılıklar olduğu sonucuna ulaşılmıştır. Değişen madde fonksiyonu analizleri ile elde edilen yüzdelerle iki karşılaştırma grubu arasında büyük farklılıklar olduğu ortaya çıkmıştır. Analizlerde gözlemlenen yapılardaki farklılıklar, TIMSS sonuçlarını matematik ve fen alanındaki genel performansları karşılaştırmak için kullanmada ciddi sınırlamaların olduğunu göstermiştir. Öğretmen (2006), ülkemizin de katıldığı PIRLS 2001 
kapsamında uygulanan okuma parçaları testlerinin psikometrik özelliklerini ABD ve Türkiye örneklemlerinde karşılaştırmalı olarak incelemiştir. Araştırma iki aşamada gerçekleştirilmiş olup, birinci aşamada okuma parçaları testlerinin ölçtüğü düşünülen yapıların kültürlere göre eşdeğer olup olmadığını ÇGDFA yöntemi ile test edilmiştir. İkinci aşamada ise test maddelerinin kültürlere göre DMF içerip içermediği MTK bağlamında parametreleri karşılaştırarak ve olabilirlik oran testi karşılaştırma yöntemleri kullanılarak araştırılmıştır. ÇGDFA sonuçlarına göre bu testlerin yapılarının kültürler arası bir eşdeğerliğinin olmadığı, parametre karşılaştırma ve olabilirlik oran testi ile yapılan analizler sonucunda maddelerinin çoğunun DMF içerdiği gözlenmiştir. Asil ve Gelbal (2012), PISA 2006 kapsamında uygulanan öğrenci anketinin kültürel ve dil bakımından ölçme değişmezliğini incelemişlerdir. Çalışmaya Avustralya, Yeni Zelanda, Amerika Birleşik Devletleri ve Türkiye örneklemleri dahil edilmiştir. Çok gruplu doğrulayıcı faktör analizi yöntemiyle öğrenci anketi maddelerinin kültürler ve dillere göre (DMF) gösterip göstermediği araştırılmıştır. Ulaşılan sonuçlara göre, ülkeler arasında kültürel ve dilsel açıdan farklılıklar arttıkça doğru orantılı olarak değişen madde fonksiyonu gösteren madde sayısının da arttığı ortaya çıkmıştır.

PISA gibi bir çok dile çevirisi yapılan uluslararası uygulamalarda orijinal hali İngilizce dilinde yazılan sorular, uzman çevirmenler tarafından başka bir dile çevrilip ardından orijinal versiyonu ile eşdeğerliğini sağlamak için tekrar İngilizceye çevrilmektedir. Bu uygulamalarda yalnızca çeviriden kaynaklı değil, eşdeğerlik sorunu oluşturan veya yanlılık kaynağı olarak gösterilen etmenler, karşılaştırılabilirlik kavramı iyi tanımlanarak belirlenmelidir. Bu etmenleri dikkatlice incelemek için ölçme araçlarında anlayışlardaki kültür farklılıklarından kaynaklanan ve dile yansıyan etkileri hakkında bilgi edinilmelidir (Goldstein, 2017). Farklı diller ve kültürler arasında yapılan ölçmelerde bu değişkenlere bağlı yanlılık gösteren ya da eşdeğerliği sağlamayan madde içerikleri mutlaka göz önünde bulundurulmalıdır. Belli bir dile özgü olan ve ayrıcalık sağlayacak anlatımlar içeren maddeler testin dışında bırakılmalıdır.

Sorular erişime açık olsaydı, ölçme değişmezliğine sınırlılık getiren maddeler incelenerek sonuçlar arasındaki farklılıklar ayrıntılı olarak yorumlanabilirdi. PISA'nın resmi internet sitesinden bu maddelere ulaşılamadığı için araştırmaya dahil edilememiştir. PISA uygulamasında maddelerin erişime açık olması ve bir çok değişken açısından içerik olarak incelenmesi, ölçme değişmezliğini sınırlayan faktörlerin araştırılması açısından önemlidir. Bu doğrultuda PISA'nın resmi sitesinde yalnızca uygulandığı yıla özgü alanın soruları değil, tüm soruların erişime açık olması önerilebilir.

\section{KAYNAKÇA}

Adams, R., \& Rowe , K. (1988). Educational research, methodology, and measurement:An international handbook. Oxford: Pergamon Press.

Akbaş, U. ve Tavşancıl, E. (2015). Farklı örneklem büyüklüklerinde ve kayıp veri örüntülerinde ölçeklerin psikometrik özelliklerinin kayıp veri baş etme teknikleri ile incelenmesi., Journal of Measurement and Evaluation in Education and Psychology, 6(1), 38-57

Algina, J. \& Crocker, L., (1986). Introduction to classical and modern test theory. New York: Holt, Rinehart and Winston.

Arffman, I. (2002). In search of equivalence: Translation problems in international literacy studies. Finland.

Arffman, I. (2010). Equivalence of translations in international reading literacy studies. Scandinavian Journal of Educational Research, 54(1), 37-59.

Asil, M., \& Gelbal, S. (2012). Cross-cultural equivalence of the PISA student questionnaire. Education ve Science, 236-249.

Asil M., \& Brown, G. (2015). Comparing OECD PISA reading in English to other languages: Identifying potential sources of non-invariance. International Journal of Testing, 16(1), 71-93.

Baker, F. B. (2016). The basics of item response theory. Ankara: Pegem Academy.

Baykal, A., \& Circi, R. (2010). Item revision to improve construct validity: A study on released science items in Turkish PISA 2006 . Procedia Social and Behavioral Sciences, 2(2), 1931-1935.

Bollen, K. A. (1989). Structural equations with latent variables. New York: Wiley.

Bonnet, G. (2002). Reflections in a critical eye: on the pitfalls of international assessment. Assessment in Education: Principles, Policy \& Practice, 9(3), 387-399.

Brown, T. A. (2006). Confirmatory factor analysis for applied research. New York: Guilford.

Cheema, J. (2012). Handling missing data in educational research using SPSS. Yayınlanmamış Doktora Tezi, George Mason University. 
Downey, R., \& King, C. (1998). Missing data in likert ratings: A comparison of replacement methods. The Journal of General Psychology, 175-191.

Elosua, P. (2011). Assessing Measurement Equivalence in Ordered-Categorical Data. Psicológica, 403-421.

Enders, C. K. (2010). Applied missing data analysis. (1. Ed.). New York: The Guilford Publications, Inc

Ercikan, K., \& Koh, K. (2005). Examining the construct comparability of the English and French versions of TIMMS. International Journal Of Testing, 23-3

Ercikan, K., \& Lyons-Thomas, J. (2013). Adapting test for use in other languages and cultures. APA Handbook of Testing and Assesment in Psychology (s. 545-569). içinde Washington: American Psychological Association.

Frank J. Fabozzi, S. M., \& Wiley , J. (2014). Model Selection Criterion: AIC and BIC. The Basics of Financial Econometrics: Tools, Concepts, and Asset Management Applications.

French, B. F., \& Finch, W. H. (2006). Confirmatory Factor Analytic Procedures for the Determination of Measurement Invariance. Structural Equation Modeling, 13(3), 378-402.

Goldstein, H. (2017). Measurement and evaluation issues with PISA. Routhledge.

Gregoric, S. (2006). Do self-report instruments allow meaningful comparisons across diverse population groups?: Testing measurement invariance using the confirmatory factor analysis framework. Medical Care, 78-94.

Grisay, A., de Jong, J. H., Gebhardt, E., Berezner, A., \& Halleux-Monseur, B. (2007). Translation equivalence across PISA countries. Journal of Applied Measurement, 8(3), 249-266.

Grisay, A., Gonzalez, E., \& Monseur, C. (2009). Equivalence of item difficulties across national versions of the PIRLS and PISA reading assessments. ERI Monograph Series: Issues and Methodologies In Large-Scale Asssesments, 2, 63-84.

Hambelton, R. K., \& Swaminathan, H. (1985). Item Response Theory. Nijhoff Publishing.

Hambleton, R. K., \& De Jong, J. A. (2003). Advances in translating and adapting educational and psychological tests. Language Testing, 127-134.

Hambleton, R. K., Merenda, P., \& Spielberger, C. (2005). Adapting educational and psychological tests for crosscultural assessment. Hillsdale, NJ: Lawrence S. Erlbaum Publishers

Herdman M., Rushby J. F., \& Badia X. (1998). A Model of Equivalence in The Cultural Adaptation of HRQol Instruments: The Universalist Approach. Ouality Of Life Research, 7(4), 323-335.

He, J., Barrera-Pedemonte, F., \& Bucholz, J. (2018). Cross-cultural comparability of non-cognitive constructs in TIMSS and PISA. Assesment in Education:Principles, Policy \& Practice, 26(4), 369-385.

He, J., \& van de Vijver, F. (2012). Bias and equivalence in cross-cultural research. Online Readings in Psychology and Culture.

Jöreskog, K.G., Sörbom, D., Du Toit, S.H.C., \& Du Toit, M. (2001). LISREL 8: New statistical features (3rd ed.). Lincolnwood, IL: Scientific Software International.

Kankaras, M., \& Moors, G. (2013). Analysis of cross-cultural comparability of PISA 2009 scores. Journal of Cross-Cultural Psychology, 43(3), 381-399.

Kim, E. S., \& Yoon, M. (2011). Testing Measurement Invariance: A Comparison of Multiple-Group Categorical CFA and IRT. Structural Equation Modeling, 212-228.

Kim, E. S., Cao, C., Wang, Y., \& Nguyen, D. T. (2017). Measurement Invariance Testing with Many Groups:A Comparison of Five Approaches. Structural Equation Modeling: A Multidisciplinary Journal.

Kline, R. B. (2016). Principles and practice of structural equation modeling. Guilford publications.

Kreiner, S., \& Christensen, K. B. (2014). Analyses of model fit and robustness. A new look at the PISA scaling model underlying ranking of countries according to reading literacy. Psychometrika, 210-231.

Lord, F. M., \& Novick, M. E. (1968). Statistical theories of mental test scores . MA: Addison-Wesley.

Lubke, G. H., \& Muthén, B. O. (2004). Applying Multigroup Confirmatory Factor Models for Continuous Outcomes to Likert Scale Data Complicates Meaningful Group Comparisons . Structural Equation Modeling A Multidisciplinary Journal, 11(4), 514-534.

Martin, M., Mullis, I., Gonzalez, E., Gregory, K., Smith, T., Chrostowski, S., O'Connor, K. (2000). TIMSS 2009 International Science Report: Findings from IEA's Repeat of The Third International Mathematics and Science Study at the Eight Grade.

McDonald, R. P. (1999). Test theory: A unified treatment. Mahwah: NJ: Lawrence Erlbaum Associates.

Meade, A. W., \& Lautenschlager, G. J. (2004). A comparison of item response theory and confirmatory factor analytic methodologies for establishing measurement equivalence/invariance. Organizational Research Methods, 7(4), 361-388.

Milli Eğitim Bakanlığı (2016). PISA 2015 International report. Ankara. Erişim adresi: https://odsgm.meb.gov.tr/www/2015-pisa-ulusalraporu/icerik/204

Meredith, W. (1993). Measurement invariance, factor analysis, and factorial invariance. Pyschometrika.

Millsap, R. E. (2011). Statistical approaches to measurement invariance. New York: US: Routledge/Taylor \& Francis Group. 
Muthén, B., and Asparouhov, T. (2013). BSEM Measurement Invariance Analysis. Mplus Web Notes: No. 17. Available online at: www.statmodel.com

Muthén, B., Asparouhov, T., \& Morin, A. J. (2015). Bayesian Structural Equation Modeling With Cross-Loadings and Residual Covariances: Comments on Stromeyer et al. Journal Of Management.

Muthén, L. K., \& Muthén, B. O. (2016). Mplus user's guide. Los Angeles, CA: Muthén \& Muthén.

Nylund, K.L., Asparouhov, T., \& Muthén, B. (2007). Deciding on the number of classes in latent class analysis and growth mixture modeling. A Monte Carlo simulation study. Structural Equation Modeling, 14, 535569.

Organisation for Economic Co-operation and Development (2016). Erișim adresi: http://www.oecd.org/education/

Oishi, S. (2006). The concept of life satisfaction across cultures: An IRT analysis. Journal of Research in Personality, 40(4), 411-423.

Öğretmen, T. (2006). Uluslararası okuma becerilerinde gelişim projesi (PIRLS) 2001 testinin psikometrik özelliklerinin incelenmesi: Türkiye-Amerika Birleşik Devletleri örneği. Ankara.

Oliveri, M. E., \& von Davier, M. (2011). Investigation of model fit and score scale comparability in international assessments. Journal of Psychological Test and AssessmentModeling, 53(3),315-333.

Onen, E. (2009). Ölçme değişmezliğinin yapısal eşitlik modellemesi teknikleri ile incelenmesi. Doktora Tezi, Ankara Üniversitesi, Ankara.

Raykov, T., Marcoulides, G. A., \& Millsap, R. E. (2013). Examining factorial invariance: A multiple testing procedure. Educational and Psychological Measurement, 73(4) 713-727.

Raykov, T., Dimitrov, D., Marcoulides, G., Li, T., \& Menold, N. (2018). Examining Measurement Invariance and Differential Item Functioning With Discrete Latent Construct Indicators: A Note on a Multiple Testing Procedure. Educational and Psychological Measurement, 78(2), 343-352.

Reise, S. P., Widaman, K. F., \& Pugh, R. H. (1993). Confirmatory factor analysis and item response theory: Two approaches for exploring measurement invariance. Psychological Bulletin, 114(3), 552-566.

Rubin, D. B., (1976). Inference and missing data. Biometrika, 63, 581-592.Salzberg, T., Sinkovics, R., \& Schlgelmich, B. (1999). Data equivalence in cross-cultural research: a comparison of classical test theory and latent trait theory based approaches. Australasian Marketing Journal, 23-38.

Sireci, S. G., \& Berberoğlu, G. (2000). Using bilingual respondents to evaluate translated-adapted items. Applied Measurement in Education, 13(3), 229-248.

Sirganci, G., Uyumaz, G., \& Yandi, A. (2020). Measurement invariance testing with alignment method: Many groups comparison. International Journal of Assessment Tools in Education, 7(4), 657-673.

Takane, Y., \& de Leeuw, J. (1987). On the relationship between item response theory and factor analysis of discretized variables. Psychometrika, 52(3), 393-408.

van de Schoot, R., Kluytmans, A., Tummers, L., Lugtig, P., Hox, J., \& Muthén, B. (2013). Facing off with Scylla and Charybdis: A comparison of scalar, partial, and the novel possibility of approximate measurement invariance. Frontiers in Psychology, 4, 1-15.

Wu, D., Li, Z., \& Zumbo, B. (2007). Decoding the meaning of factorial invariance and updating the practice of multi-group confirmatory factor analysis: A demonstration with TIMSS data. Practical Assesment, Research \& Evaluation, 12(3), 1-26. 
Ek A. Anadili İngilizce Olan Ülkelerde DFA İçin Kullanılan Mplus 8.0 Kodları

TITLE: this is an example of a CFA with categorical factor indicators

DATA: FILE IS ING.dat;

VARIABLE: NAMES ARE u1-u28;

CATEGORICAL ARE u1-u28;

MISSING ARE ALL(999);

MODEL: f1 BY u1-u28; 
Bağdu Söyler, P., Aydın, B., Atılgan, H. / PISA 2015 Dil Gruplarına Göre Madde Parametreleri: İkili Değişkenlerle Ölçme Değişmezliği Çalışması

\section{Ek B. Anadili İngilizce Olmayan Ülkelerde DFA İçin Kullanılan Mplus 8.0 Kodları}

TITLE: this is an example of a CFA with categorical factor indicators

DATA: FILE IS NONING.dat;

VARIABLE: NAMES ARE u1-u28;

CATEGORICAL ARE u1-u28;

MISSING ARE ALL(999);

MODEL: f1 BY u1-u28; 
Ek C. İkili Puanlanmış Maddelerde Ölçme Değişmezliği İçin Kullanılan Mplus 8.0 kodları

$\mathrm{M}_{0}$ Serbest Modeli İçin Yazılan Kod:

TITLE: Raykov (2018) M0

DATA: FILE = multicfaALL1.dat;

VARIABLE: NAMES = g u1-u28;

CATEGORICAL $=\mathrm{u} 1-\mathrm{u} 28$;

KNOWNCLASS $=\mathrm{C}(\mathrm{g}=1 \mathrm{~g}=2) ; \mathrm{g}=1 \mathrm{ING}, \mathrm{g}=2$ NOing

CLASSES $=\mathrm{C}(2)$;

MISSING=ALL(999);

ANALYSIS: ESTIMATOR = ML;

TYPE = MIXTURE;

ALGORITHM = INTEGRATION;

MODEL:

\%OVERALL\%

f1 BY u1* (L1)

u2-u28 (L2-L28);

[u1\$1-u28\$1](T1-T28);

[f1@0];

f1@1;

$\% \mathrm{C} \# 2 \%$

f1 BY u1*(L1)

u2-u28 (L2-L28);

[u1\$1-u28\$1](T1-T28);

[f1*];

$\mathrm{f} 1 *$;

Madde Eşik Değerlerinin Serbest Bırakıldığı Bir Model Örneği $\left(M_{1}-M_{28}\right)$ :

TITLE: Raykov (2018) M1 (relase first threshold)

!LISTWISE $=\mathrm{ON}$;

DATA: FILE = multicfaALL1.dat;

VARIABLE: NAMES = g u1-u28;

CATEGORICAL $=\mathrm{u} 1-\mathrm{u} 28$;

KNOWNCLASS $=\mathrm{C}(\mathrm{g}=1 \mathrm{~g}=2) ; \mathrm{g}=1 \mathrm{ING}, \mathrm{g}=2$ NOing

CLASSES $=\mathrm{C}(2)$;

MISSING=ALL(999);

ANALYSIS: ESTIMATOR = ML;

TYPE = MIXTURE;

ALGORITHM = INTEGRATION;

MODEL:

$\%$ OVERALL \%

f1 BY u1* (L1)

u2-u28 (L2-L28);

[u1\$1-u28\$1](T1-T28);

[f1@0];

f1@1;

$\% \mathrm{C} \# 2 \%$

f1 BY u1*(L1)

u2-u28 (L2-L28);

[u2\$1-u28\$1](T2-T28);

[u1\$1*];

[f1*];

f1*; 
Bağdu Söyler, P., Aydın, B., Atılgan, H. / PISA 2015 Dil Gruplarına Göre Madde Parametreleri: İkili Değişkenlerle Ölçme Değişmezliği Çalışması

Madde faktör Yüklerinin Serbest Bırakıldığı Bir Model Örneği $\left(\mathrm{M}_{29}-\mathrm{M}_{56}\right)$ :

TITLE: Raykov (2018) M29 (relase first loading)

!LISTWISE=ON;

DATA: FILE = multicfaALL1.dat;

VARIABLE: NAMES = g u1-u28;

CATEGORICAL $=\mathrm{u} 1-\mathrm{u} 28$;

KNOWNCLASS $=\mathrm{C}(\mathrm{g}=1 \mathrm{~g}=2) ; \mathrm{g}=1 \mathrm{ING}, \mathrm{g}=2$ NOing

CLASSES $=\mathrm{C}(2)$

MISSING=ALL(999);

ANALYSIS: ESTIMATOR = ML;

TYPE = MIXTURE;

ALGORITHM = INTEGRATION;

MODEL:

\%OVERALL\%

f1 BY u1*(L1)

u2-u28 (L2-L28);

[u1\$1-u28\$1](T1-T28);

[f1@0];

f1@1;

$\% \mathrm{C} \# 2 \%$

f1 BY u1*

u2-u28 (L2-L28);

[u1\$1-u28\$1](T1-T28);

$[\mathrm{f} 1 *]$;

$\mathrm{f} 1^{*}$; 